\title{
Ecological repercussions of historical fish extraction from the Southern Ocean
}

\author{
David G Ainley ${ }^{1}$ \& Louise K Blight ${ }^{2, *}$ \\ ${ }^{1}$ H.T. Harvey and Associates, 983 University Avenue, Bldg D, Los Gatos, CA 95032, USA; ${ }^{2}$ Project Seahorse, Fisheries \\ Centre, University of British Columbia, 2202 Main Mall, Vancouver, BC, Canada V6T 1Z4
}

\begin{abstract}
A major mid-1980s shift in ecological structure of significant portions of the Southern Ocean was partially due to the serial depletion of fish by intensive industrial fishing, rather than solely to climate factors as previously hypothesized. Over a brief period (1969-1973), several finfish stocks were on average reduced to $<50 \%$, and finally (mid-1980s) to $<20 \%$, of original size. Despite management actions, few stocks have recovered and some are still declining. Most affected species exhibit K-selected life-history patterns, and before exploitation presumably fluctuated in accordance with infrequent strong year classes, as is true of such fish elsewhere. A climate regime, the Southern Annular Mode, once oscillated between two states, but has remained in its 'positive mode' since the time of the fish extraction. This may have increased finfish vulnerability to exploitation. As breeding stocks decreased, we hypothesize that availability of annually produced juvenile fish fed upon by upperlevel predators remained low. Correlations between predator populations and fish biomass in predator foraging areas indicate that southern elephant seal Mirounga leonina, Antarctic fur seal Arctocephalus gazella, gentoo penguin Pygoscelis papua, macaroni penguin Eudyptes chrysolphus and 'imperial' shag Phalacrocorax spp. - all feeding extensively on these fish, and monitored at Marion, Crozet, Kerguelen, Heard, South Georgia, South Orkney and South Shetland Islands, where fishing was concentrated - declined simultaneously during the two periods of heavy fishing. These patterns indicate the past importance of demersal fish as prey in Antarctic marine systems, but determining these interactions' ecological mechanisms may now be impossible.
\end{abstract}

Keywords Antarctic marine ecosystem, climate change, ocean food webs, overfishing regime shift, Southern Annular Mode
Correspondence:

David G Ainley, H.T

Harvey and Associ-

ates, 983 University

Avenue, Bldg D, Los

Gatos, CA 95032,

USA

Tel.: + 1 (415) 332-

5718

Fax: + 1 (408) 458-

3210

E-mail: dainley@

penguinscience.com

"Current address: Centre for Applied Conservation

Research, University of British Columbia, 2424 Main Mall, Vancouver, BC,

Canada V6T 1 Z4.

Received 3 Jan 2008 Accepted 30 May 2008

$\begin{array}{lr}\text { Introduction } & \mathbf{2} \\ \text { Methods } & \mathbf{3} \\ \text { Data sets } & 3 \\ \text { Statistical methods } & 5 \\ \text { Results } & \mathbf{5} \\ \text { Historical fish extraction } & 5 \\ \quad \text { South Georgia and vicinity: FAO Subarea 48.3 } & 7 \\ \quad \text { Antarctic Peninsula and South Shetland Islands: FAO Subarea 48.1 } & 7\end{array}$ 


\begin{tabular}{lr} 
South Orkney Islands: FAO Subarea 48.2 & 7 \\
Southern Indian Ocean sector: FAO Area 58 & 7 \\
Kerguelen, McDonald: FAO Subarea 58.5 & 8 \\
Kerguelen - Division 58.5.1 & 8 \\
McDonald and Heard - Division 58.5.2 & 8 \\
Crozet - FAO Subarea 58.6 & 8 \\
Marion and Prince Edward islands - FAO Subarea 58.7 & 8 \\
Predator foraging behaviour, diet and population trends & 8 \\
Southern elephant seal & 8 \\
Antarctic fur seal & 11 \\
Gentoo penguin & 12 \\
Macaroni penguin & 13 \\
Imperial cormorant & 14 \\
Discussion & $\mathbf{1 4}$ \\
General thoughts & 14 \\
A perspective on the food web structure of the SO & 16 \\
Final thoughts & 17 \\
Acknowledgements & $\mathbf{1 8}$ \\
References & $\mathbf{1 8}$ \\
Appendix & $\mathbf{2 4}$ \\
\hline
\end{tabular}

"Their specific biological characteristics, such as slow growth rates and low fecundity, make Antarctic coastal fish particularly susceptible to overfishing. It is therefore not surprising ... they were overexploited within a few years after the commencement of fishing, thus paralleling the history of whaling on a much shorter time scale as one of successive discovery, exploitation and depletion of each new stock". (Kock 1992, p. xiv)

\section{Introduction}

Since the concurrent advent of satellite-assisted remote sensing, the maturation of a number of decades-long modern biotic data sets, and the discovery that Earth's climate is changing suddenly, the marine research community has been focused on the effect of climate change on marine species and communities (Laevastu 1993; Beaugrand et al. 2002; Edwards and Richardson 2004; Perry et al. 2005; Ducklow et al. 2007; Murphy et al. 2007). From this effort has come an appreciation for the time scales at which climate affects food webs, from short term (e.g. El Niño-Southern Oscillation) to decadal (e.g. North Atlantic Oscillation, Pacific Decadal Oscillation [PDO]) and even longer (e.g. Little Ice Age). As a result, the concept has emerged of 'regime shifts', or step-like changes in the mean state or baseline of a system (Mantua and Hare
2002). These shifts have consistently been found to affect all levels of a marine ecosystem (Aebischer et al. 1990; McGowan et al. 1998; Planque and Taylor 1998; Hare and Mantua 2000; O'Brien et al. 2000; Vandenbosch 2000; Ainley and Divoky 2001; Thompson and Ollason 2001).

While most of this climate research has involved oceans close to civilization, where the accumulation of data has been occurring for many decades if not for centuries, the Antarctic portion of the Southern Ocean (SO, ocean south of the Polar Front) has not been ignored despite its relative remoteness. However, the biotic data sets available are much shorter than those for the Atlantic and Pacific oceans, and as they extend no more than 50 years are barely long enough for informative statistical analysis. Nevertheless, as noted in other parts of the world's oceans (see Beamish et al. 1999), a step-like shift in SO weather and the biota is evident during the mid1970s and again around 1990 (Ainley et al. 2005; Jenouvrier et al. 2005). Like the atmospheric 'oscillations' driving Northern Hemisphere regime shifts, those of the SO are related to shifting pressure systems - in this case, the Antarctic Oscillation or the Southern Annular Mode (SAM). Regional shifts in temperatures, winds and sea-ice cover have been affected by the SAM (Lefebvre et al. 2004; Stammerjohn et al. 2008) and so in turn have the biota, from benthic to epipelagic organisms (reviewed in 
Ainley et al. 2005; Jenouvrier et al. 2005; Ducklow et al. 2007; Murphy et al. 2007).

Many statistically significant correlations and models have been developed and invoked to explain the effects of these changed climate regimes on the biota. However, the majority $(60-70 \%)$ of the population trend variation (e.g. penguin or pinniped population change in response to sea-surface temperature or sea-ice extent: Croxall 1992; Fraser et al. 1992; Wilson et al. 2001; Weimerskirch et al. 2003) in these models often remains unexplained, and thus an analysis of changing climate only provides part of the picture. Other factors must also be contributing, and to explain more of this variation, we use these very same data sets and hypothesize herein that the intense serial depletion of certain prey stocks by early commercial fisheries was also directly or indirectly involved. In region after region worldwide, including the SO, this extraction process began at the top of the food web and worked down, and has accelerated during the last 50 years (Pauly et al. 1998; Myers and Worm 2003; Pauly and Maclean 2003; Pauly and Palomares 2005; Morato et al. 2006; Daskalov et al. 2007; Kock 2007).

In most regions, this 'fishing down the food web' began so long ago that it is a major challenge to assess food web effects (see Schrope 2006). However, because the finfishing industry ventured relatively recently into the SO, i.e. only since the late 1960s (Kock 1992; Kock and Jones 2005), and because an appreciable amount of documentation exists thanks to the Food and Agriculture Organization (FAO) of the UN, the Convention for the Conservation of Antarctic Marine Living Resources (CCAMLR) and researchers in many Antarctic national programs, it has been possible to reconstruct historical fish extraction, as detailed in Kock (1992), Pauly et al. (1998), Myers and Worm (2003), Morato et al. (2006) and elsewhere. Using these reconstructions, we attempt herein to deduce the degree to which, like climate, the historical (premanagement) depletion of fish stocks influenced the species and trophic structure of the upper portion of the SO ecosystem. We acknowledge that the mass removal of fur seals and, later, baleen whales immediately preceding the fish extraction also had profound effects on the Antarctic marine ecosystem (AME: Laws 1977a,b; Ballance et al. 2006; Emslie and Patterson 2007). But whereas that aspect of predator removal has been extensively addressed (see also Beddington and May 1982; Bengtson and
Laws 1985), this is not the case for fish (Ainley et al. 2007).

Herein we review the progression of historical SO fishing and assess its past and continuing impacts on the upper food web using several seal and marine bird species in certain areas of the AME - most species having been chosen by CCAMLR in their Ecosystem Monitoring Program (CEMP), which was put in place after many fish stocks were already depleted (CCAMLR 2007a). After long debate, CEMP validated a method using agreed-upon protocols and data from individual colonies to monitor respective regional food webs (see CCAMLR 2007a, and also e.g. Croxall 1992; Croxall et al. 1988a, 2002; Weimerskirch et al. 2003). Thus, we confine our analyses to that part of the SO covered by CEMP, extending from northern insular and continental shelf breaks to pelagic waters (Kock 1992, Ch. 15). This is the realm of the well-known Antarctic krill Euphausia superba (Beddington and May 1982; Nicol 2005; Siegel 2005; Murphy et al. 2007). These northern shelves, slopes and subsea plateaus first saw the explosion in fishing effort (see Gon and Heemstra 1990; Kock 1992; Duhamel et al. 2005). Moreover, owing to the dispersion of national research bases, the longest SO predator data sets come from these locations and it is these data sets that have been extrapolated to apply to the AME at large (Croxall 1992; Croxall et al. 2002; Weimerskirch et al. 2003) and which we will use for our regional analyses.

\section{Methods}

\section{Data sets}

We concentrate on those predator species for which estimates of population size have been collected regularly for decades and which are known to eat substantial amounts of fish - Pinnipedia: southern elephant seal (Mirounga leonina), and Antarctic fur seal (Arctocephalus gazella); Spheniscidae: gentoo penguin (Pygoscelis papua), and macaroni penguin (Eudyptes chrysolophus); and various forms of the 'imperial' cormorant Phalacrocorax spp. (Phalacrocoracidae: Antarctic shag Phalacrocorax brandsfieldensis, Heard shag Phalacrocorax nivalis, South Georgian shag Phalacrocorax georgianus, Crozet shag Phalacrocorax melanogenis, Kerguelen shag Phalacrocorax verucosus). Moreover, most of these species' population trajectories previously have been tied to climate forcing, with analyses made possible by the 
length of the available time series (Reid and Croxall 2001; Weimerskirch et al. 2003; McMahon et al. $2005 \mathrm{~b})$. With the exception of those for elephant seal, these earlier population data sets have been subsumed by CCAMLR, which has certified the original data collection protocols for continued collection of population data as part of CEMP. We note here that predator breeding populations can respond both immediately to changes in prey availability - by altering the proportion of individuals in the population that attempts breeding in a given year - and over the longer term, by the attrition of adults through mortality, increased or not, without replacement owing to the depression in breeding productivity (Reid and Croxall 2001; Weimerskirch et al. 2003; McMahon et al. 2005b).

We first review the history of the fishing industry primarily through the use of area-based CCAMLR/ FAO catch data both published and unpublished (Kock 1992; FAO 2007) on the historically mostfished species, namely family Nototheniidae: Patagonian toothfish Dissostichus eleginoides, marbled notothenia Notothenia rossii, grey notothenia Lepidonotothen squamifrons, yellowfin notothen Patagonotothen guntheri, humped rockcod Gobionotothen gibberifrons; and family Channichthyidae: mackerel icefish Champsocephalus gunnari, unicorn icefish Channichthys rhinoceratus, blackfin icefish Chaenocephalus aceratus, South Georgia icefish Pseudochaenichthys georgianus; as well as members of the family Myctophidae, e.g. Electrona spp. (Table 1). In addition, although information on most Antarctic fish populations is inadequate to conduct stock assessments (Kock 1992; Garibaldi and Caddy 2004), Kock (1992) presents estimates of biomass through virtual population analysis (VPA), and we show those results alongside the catch data where available. It is clear that in the case of the SO, fish population estimates correlate closely with total catch (Statistical methods). Thus, we discuss fish population trends based on trends both in past catch rates and, where data are available, on population estimates.

We then review the foraging ecology of fish predators, paying particular attention to (i) known

\begin{tabular}{|c|c|c|c|c|}
\hline & $\begin{array}{l}\text { Date } \\
\text { fishery } \\
\text { initiated }\end{array}$ & $\begin{array}{l}\text { Date } \\
\text { peak } \\
\text { catch }\end{array}$ & $\begin{array}{l}\text { Date fishery } \\
\text { closed by } \\
\text { CCAMLR }\end{array}$ & $\begin{array}{l}\text { Stock } \\
\text { remaining } \\
(\%)\end{array}$ \\
\hline \multicolumn{5}{|c|}{ South Georgia and vicinity: Subarea 48.3} \\
\hline Champsocephalus gunnari & 1970 & 1976 & 1988 & $<10$ \\
\hline \multicolumn{5}{|l|}{ Gobionotothen gibberifrons } \\
\hline \multicolumn{5}{|c|}{ Pseudochaenichthys georgianus } \\
\hline Chaenocephalus aceratus & $1975^{\star}$ & 1977 & 1999 & $25-40$ \\
\hline Notothenia rossii & 1969 & 1969 & 1985 & $<5$ \\
\hline Patagonotothen guntheri & 1978 & 1980 & 1990 & $\sim 20$ \\
\hline \multicolumn{5}{|c|}{ Antarctic Peninsula and South Shetland Islands: Subarea 48.1} \\
\hline C. gunnari & 1978 & 1978 & 1990 & $<5$ \\
\hline Chaenodraco wilsoni & 1978 & 1978 & 1990 & $?$ \\
\hline N. rossii & 1978 & 1979 & 1990 & $<10$ \\
\hline \multicolumn{5}{|c|}{ South Orkney Islands: Subarea 48.2} \\
\hline C. gunnari & 1977 & 1977 & 1990 & $<5$ \\
\hline G. gibberifrons & 1977 & 1982 & 1990 & 40 \\
\hline N. rossii & 1979 & 1979 & 1990 & $<10$ \\
\hline \multicolumn{5}{|l|}{ Kerguelen Islands: Division 58.5.1 } \\
\hline C. gunnari & 1970 & 1977 & & $\sim 30$ \\
\hline D. eleginoides & 1977 & 1984 & & $\sim 15$ \\
\hline Lepidonotothen squamifrons & 1971 & 1972 & 1989 & $<5$ \\
\hline N. rossii & 1970 & 1971 & & $<10$ \\
\hline \multicolumn{5}{|l|}{ Heard Island: Division 58.2.2 } \\
\hline C. gunnari & 1971 & 1976 & 1989 & $\sim 15$ \\
\hline D. eleginoides & 1995 & 1996 & & $?$ \\
\hline
\end{tabular}

*Fish known to have been taken earlier, although there are no data available for these earlier fisheries. A question mark indicates no data available.

Table 1 A summary of the history of most-fished species in the Southern Ocean (by FAO statistical area; data from Kock 1992; Kock et al. 2004; CCAMLR 2005a-e) 
prey formerly or currently subject to a targeted fishery; (ii) the years when diet studies were conducted relative to fish depletion (see above quote from Kock 1992); and (iii) predator foraging areas relative to the fishing grounds and to the years when foraging behaviour was investigated.

\section{Statistical methods}

Finally, we correlated predator population trajectories (data from the literature) to levels of fish biomass (and when not available, fish catch) in the CCAMLR/FAO Fishing Area, Subarea, or Division corresponding to each population's foraging area (Spearman and Pearson correlation, with Bonferroni correction; SYSTAT 11.0; Systat Software Inc., San Jose CA USA 95110). We did not use more sophisticated correlation methods (Weimerskirch et al. 2003), because time series were short, we were not dealing with multiple variables, and in some cases, there were problems with normality (see below). For predator counts and fish biomass/ catch, we in-filled missing values by averaging values immediately on either side of the missing value. We included such interpolated values in correlations for a particular data set only if all other values in a given comparison were actual (not interpolated, i.e. only one data series per correlation contains interpolated values). Although we realize that the use of modelled fish biomass (VPA) and fish catch data as a proxy for population trends can be controversial, global fish stocks are generally declining as a result of over-exploitation (Pauly et al. 2002; Worm et al. 2007), and that trend clearly exists in the case of the historical SO extraction treated here. Kock (1992, pp. 125-131) discussed in detail various ways to estimate biomass in SO fisheries, with the biases of each method. He settled on VPA as the most appropriate, and we follow his lead; VPA is better than raw catch to characterize the amount of fish available, as it contains compensation for fishing/sampling effort. The fishing was carried out mainly by Eastern Block countries during the Cold War, in a region with no fish-treaty regulations on gear size or fishing technique, and no traditionally described market forces involved in how many fish to catch (see Kock 1992). Moreover, almost all of the fish depletion occurred prior to the regulatory appearance of CCAMLR in 1982.

With regard to elephant seals at Crozet and Kerguelen islands, where data series were twice the length of those for the other predators, we correlated seal numbers with fish catch, year and a 3-year running mean of air temperature (seals and temperature data from Weimerskirch et al. 2003). While there are valid concerns about the use of air temperature as a proxy for ocean temperature in coastal continental areas, these air temperature data are credible as they were recorded at the remote oceanic islands where the seals were counted (i.e. little, if any, continental influence). Following Weimerskirch et al. (2003), we assumed that air/ocean temperature acts as an indirect proxy for climate-induced changes to ocean productivity and general prey availability but also, as noted, that fish catch was a direct proxy to prey availability itself. As a result of missing values (which we could not interpolate owing to our 'rules' for doing so; see above), only the number of seals was normally distributed, and transformations did not improve the dispersion of stock depletion or air temperature. Thus, we used Spearman rank correlations.

Obviously, interpreting the above correlations in some cases proved to be problematic as (i) intense fish extraction often overlapped only a portion of a predator's population data and/or (ii) fish subsequently disappeared from the system or the fishery was closed and no further data became available. Therefore visual inspection of relationships is also important, showing where critical inflection points in fish abundance data and predator abundance data coincide.

Throughout we identify the austral summer fishing seasons, e.g. 1978-79, using the initial year, i.e. 1978 .

\section{Results}

\section{Historical fish extraction}

Significant levels of exploratory fishing, primarily confined to the Scotia Sea, commenced in 1962. Thereafter, as noted by Kock (1992; see quote at the start of paper), depletion was serial, with fishing effort moving from one stock and geographical area to the next (see also Pauly et al. 1998; Morato et al. 2006). A de facto ecological experiment, i.e. unregulated large-scale extraction, began in 1969 in the vicinity of South Georgia and spread to the Kerguelen Islands the following season (Table 1). By 1992, about 3 million metric tonnes of fish had been taken from the SO (Fig. 1), a figure that does not include 


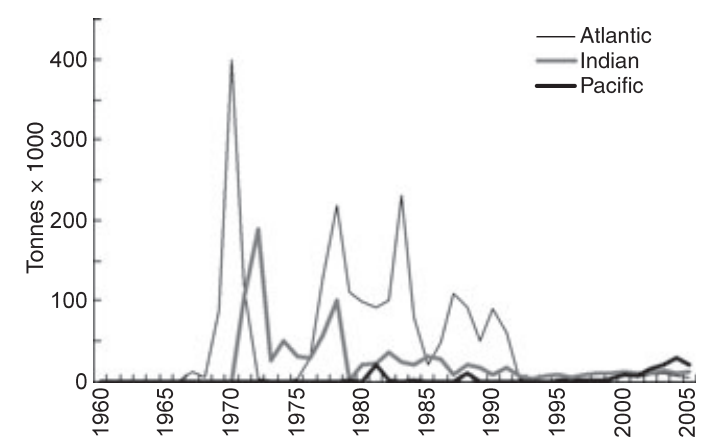

Figure 1 A summary of fish catch, all species, in three sectors of the Southern Ocean (data from FAO on-line database, http://www.fao.org). illegal and unreported catch, which was apparently initiated in about that year (Agnew et al. 2008). About 2.08 million of those tonnes (69\%) were from the Atlantic sector (FAO Area 48; Fig. 2), with 1.74 million tonnes $(83.4 \%)$ coming from the area around South Georgia. For the Indian Ocean sector (FAO Area 58; Fig. 2), 872000 tonnes (94.4\%) of the 924000 tonnes caught came from 'the vicinity of' the Kerguelen Islands (FAO Division 58.5.1, Fig. 2; Kock 1992, 1994). In the Atlantic and Indian Ocean sectors, the initial take - over only four seasons, 1969-1972 - was huge and was never to be repeated. A lesser peak followed during the late-1970s to mid-1980s, with CCAMLR
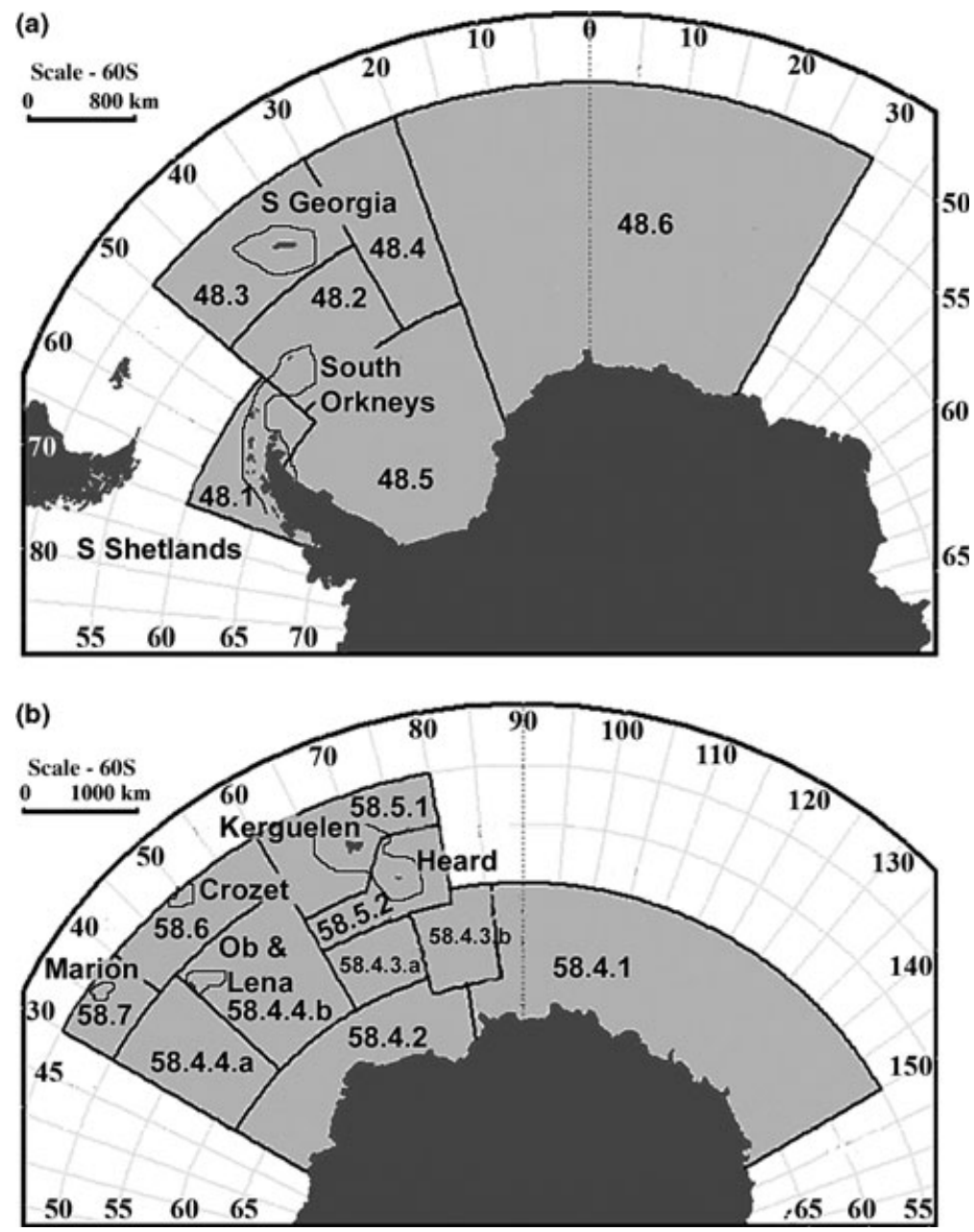

Figure 2 (a) FAO Fishing Area 48: Atlantic Sector; and (b) FAO Fishing Area 58: Southern Indian Ocean sector. Geographical descriptions at http://www.fao.org/fi/website/FIRetrieveAction.do?dom=areaandxml=Area48.xml; \& $=$ Area 58.xml. Fine lines surrounding islands indicate extent of the shelves where fishing was concentrated. 
and its fisheries management regimes established in 1982 in response to concerns about fishing pressure on Antarctic stocks, but after most of the serial depletion had occurred (Fig. 1; CCAMLR's first conservation measures were not established until 1985). Fishing in the Antarctic Pacific Sector has only recently gained momentum, beginning with an increase in reported take of Antarctic toothfish Dissostichus mawsoni, although fishing in the sub-Antarctic portion of this sector has a long history. The current (and past) illegal take in the Antarctic is unknown. Below we provide further details for each FAO Subarea or Division within the SO.

South Georgia and vicinity: FAO Subarea 48.3

Reported commercial fishing began in the $\mathrm{SO}$ in 1969, on N. rossii in Subarea 48.3 (Table 1, Fig. 2). The total catch of that species from 1969 to 1989 was 571028 tonnes, with 501262 tonnes being caught in the first 2 years, 1969 and 1970 (Kock 1992); the fishery was closed in 1985 and thereafter only a by-catch of 300 tonnes per annum was permitted (CCAMLR 2005b). Catches of C. gunnari commenced in 1970 and were low until 1975 but then peaked the following year at 93595 tonnes and declined substantially thereafter. A second peak occurred in 1981 and 1982 at 54040 and 178824 tonnes respectively; finally, a year after a peak of 80586 tonnes in 1986, CCAMLR also closed this fishery (Kock 1992, CCAMLR 2005b). It was sporadically reopened and closed, beginning in 1987, albeit at a drastically reduced catch limit of 8000 tonnes; since then, the annual quota has ranged from 0 to 26000 tonnes but the maximum annual catch has not surpassed 4114 tonnes (CCAMLR 2005b).

Catches of D. eleginoides on the order of several hundreds of tonnes per annum were reported between 1976 and 1985, but the species was likely also taken by the Soviet fishery in the late 1960s (Kock 1992, CCAMLR 2005a). This fishery has largely been confined to the insular shelfbreak and slope. A fishery in the 1980s for Electrona carlsbergi initially had an annual catch limit of 109000 tonnes but the highest catch was 29673 tonnes; the limit later included 'provisions' (presumably an increased limit) for the fishery to expand to nearby Shag Rocks. This stock was last assessed in 1994, but as the mean age of this fish in the experimental fishery is 5 years (i.e. subadult, indicating lack of matura- tion of the age-structure), CCAMLR closed the fishery in 2003 to await another stock assessment (CCAMLR 2004, 2007b).

Antarctic Peninsula and South Shetland Islands: FAO Subarea 48.1

In the vicinity of the NW Antarctic Peninsula, exploitation began in 1978, but was profitable for only two seasons - 1978 and 1979 - as stocks were over-fished at the fishery's outset (Kock 1992; Fig. 2). Total catches for $N$. rossii and C. gunnari from 1978 to 1989 were 19233 and 41396 tonnes, respectively, for each species. However, almost the entire catch of C. gunnari (35930 tonnes) was taken in 1978 , and of $N$. rossii in 1979 (Kock 1992). The 1979 catch of N. rossi (18 763 tonnes) exceeded the estimated stock size (15 663 tonnes) and the very limited catch of this species in subsequent seasons suggest that most of the stock had been removed. There has been no indication of population recovery (Kock 1992; CCAMLR 2004, Barrera-Oro and Marschoff 2007). Spiny icefish Chaenodraco wilsoni ( $\geq 14450$ tonnes) was the only other species for which there was a documented target fishery (data from the former Eastern Bloc countries known to have fished this area are largely unavailable; Kock 1992; Kock et al. 2004). This entire Subarea was closed to commercial finfishing after the 1989 season. It was last surveyed in 2003, with results showing stock condition insufficient to reopen fishing (CCAMLR 2004).

South Orkney Islands: FAO Subarea 48.2

Commercial fishing extended to this Subarea in 1977 (Table 1, Fig. 2), but was profitable for only its first season due to over-fishing of target species (Kock 1992). Total catch for C. gunnari, 19771989, was 187898 tonnes, with 138895 and 21349 tonnes taken in the first and second seasons, respectively. By the time the fishery was closed, populations were estimated to be at $<5 \%$ of original size (Kock 1992). Gobionotothen gibberifrons was the only other species reportedly taken in substantial numbers (total catch 38821 tonnes). The catch of N. rossii was 2888 tonnes, but this stock may never have been large (Kock 1992). As with 48.1 , Subarea 48.2 was closed by CCAMLR to the finfishery after the 1989 season. The Subarea was last surveyed in 1999, with results indicating stock condition at a level insufficient to reopen fishing (CCAMLR 2004). 
Southern Indian Ocean sector: FAO Area 58

According to Kock (1992), exploratory fishing began on the Kerguelen and Crozet shelves in the Indian Ocean sector in 1967 (Fig. 2). Green (2006) reported that the fishery began in 1966, and Duhamel et al. (2005) reported exploratory fishing in 1958, 1960 and 1961 by USSR vessels. Largescale fishing commenced in 1970 (Table 1). The fishery was extended to the $\mathrm{Ob}$ and Lena Banks (Division 58.4.4) in 1977 and to the coast of Antarctica in 1982 (Divisions 58.4.1 and 58.4.2; Kock 1992). As noted above, as of 1992 nearly 95\% (by weight) of the fish taken in this sector were caught in the vicinity of the Kerguelen Islands (Kock 1994).

Kerguelen, McDonald: FAO Subarea 58.5

Kerguelen - Division 58.5.1. This is the region where commercial fishing in the Indian Ocean sector began (Table 1). Total catches of note from its inception in 1970 through 1989 are as follows: N. rossii 297514 tonnes, C. gunnari 323487 tonnes and L. squamifrons 196953 tonnes (Kock 1992; Duhamel et al. 2005). Fishing for D. eleginoides began in 1977 and peaked in 1984 at 6677 tonnes, with catches subsequently declining. France declared an Exclusive Economic Zone (EEZ) around Kerguelen and Crozet islands in 1978 and fishing for this species outside territorial waters has been prohibited since 2003 (CCAMLR 2007b), although that has not stopped the illegal fishing (Knecht 2006).

For N. rossii, $56 \%$ of the total catch was taken in the first 2 years of the fishery (1970 and 1971; annual catch totalled 63000 and 104000 tonnes, respectively). Initial population size of $N$. rossii for this area was estimated at 185 000-290 000 tonnes. Total reported catch exceeded the maximum estimated population size and in 1984 stock size was approximately $2-5 \%$ of the original unharvested population, increasing to $7-10 \%$ of the pristine stock size in 1988 (Kock 1992). Targeted fishing on this species has been prohibited since 1985 , and the ban imposed then by CCAMLR is still in effect. For C. gunnari, Kock (1992) reported variable catch levels from the inception of commercial fishing in 1970 through 1988. No catches are reported in the most recent CCAMLR fishery reports, indicating that the fishing is not profitable (Duhamel et al. 2005; CCAMLR 2007c).
McDonald and Heard - Division 58.5.2. Kock (1992) reported that about 10000 of 72893 tonnes of $C$. gunnari fished in 1977 were "probably caught on the Kerguelen-Heard Ridge and the Heard Island shelf'. Because around $95 \%$ of the fish caught in Area 58 are from the vicinity of the Kerguelen Islands, however, historical catches at McDonald and Heard have likely been commensurately low. Champsocephalus gunnari is still fished in Australian territorial waters at Heard and McDonald islands and is now considered the second 'principle species' in the fishery after D. eleginoides. Total Allowable Catch for 2006 for C. gunnari was 42 tonnes and for L. squamifrons was 80 tonnes (Australian Fisheries Management Authority 2007). The catch for D. eleginoides declined from 6677 tonnes in 1984 to 1630 tonnes by 1989 (CCAMLR 2007b).

\section{Crozet - FAO Subarea 58.6}

Marion and Prince Edward islands - FAO Subarea 58.7. Fishing for D. eleginoides in Subarea 58.6 has been prohibited outside the Crozet EEZ since 2002 (CCAMLR 2007b). The catch limit for D. eleginoides (1218 tonnes in 2004) at the Crozet Islands has not been reached because some fishermen avoid fishing in the area - apparently because of high levels of depredation by killer whales Orcinus orca and sperm whales Physeter macrocephalus on toothfish catches (CCAMLR 2005f, Roche and Guinet 2007). Since 1998, the fishery for D. eleginoides has been closed outside South Africa's EEZ around Prince Edward Islands (CCAMLR 2007b). Despite this, the illegal fishery in the area is very successful (CCAMLR 2005g).

\section{Predator foraging behaviour, diet and population trends}

\section{Southern elephant seal}

Three 'metapopulations' of this species have been identified on the basis of movements of tagged individuals: (i) Scotia Sea/Antarctic Peninsula, centred at South Georgia; (ii) Macquarie Island, and sub-Antarctic islands south of New Zealand; and (iii) Kerguelen/Heard/Crozet/Marion islands (Laws 1994). Upon decimation by sealers in the 1700 s and 1800s (on the order of 2 million taken from the Scotia Sea region alone; Laws 1960), all began to recover but this recovery was followed by a subsequent decline, especially since the early-tomid-1980s. Although numbers at South Georgia have been stable, numbers to the south in that 
metapopulation are declining (but those in temperate waters off Valdes Peninsula, Argentina, are increasing; Laws 1994; McMahon et al. 2005a). We do not consider the Macquarie Island subpopulation in this paper, mainly because of difficulty in accessing fish catch data in its vicinity and that of the Campbell Plateau. However, that population, too, with a large proportion of its foraging activity occurring in Antarctic waters, declined precipitously in the mid-1980s, following a recovery from an earlier decrease (Hindell et al. 1994).
The diet of this species is notoriously difficult to study (see summary in Green 2006). The basic problems are not only that most individuals are fasting by the time they come ashore, but that squid beaks can remain in stomachs for weeks while fish otoliths disappear within a day (Harvey and Antonelis 1994). Using elephant seals as samplers, much has been learned about SO cephalopods, but not fish. Comparing the ratio of fish eye lenses to squid beaks, Green and Burton (1993) estimated that fish contributed $77 \%$ to the diet of Heard Island

Table 2 A summary of the timing of diet studies among predators and sites (Heard, Marion, Kerguelen, Crozet, South Georgia, South Orkney and South Shetland islands) treated in this paper, relative to the initial major fish extraction events (shaded).*

\begin{tabular}{|c|c|c|c|c|c|}
\hline & Southern elephant seal & Antarctic fur seal & Gentoo penguin & Macaroni penguin & Imperial cormorant \\
\hline$>1969$ & 45,48 & 42 & & & \\
\hline \multicolumn{6}{|l|}{1969} \\
\hline \multicolumn{6}{|l|}{1970} \\
\hline \multicolumn{6}{|l|}{1971} \\
\hline \multicolumn{6}{|l|}{1972} \\
\hline \multicolumn{6}{|l|}{1973} \\
\hline \multicolumn{6}{|l|}{1974} \\
\hline \multicolumn{6}{|l|}{1975} \\
\hline 1976 & & & 19 & 19 & \\
\hline 1977 & & & 16 & & \\
\hline \multicolumn{6}{|l|}{1978} \\
\hline 1979 & & & & & 1 \\
\hline 1980 & & & 2,16 & 2 & 13 \\
\hline 1981 & & & & & 13 \\
\hline 1982 & & 53 & 2 & & 2 \\
\hline 1983 & & & & 18 & 2 \\
\hline 1984 & & & 21,23 & 18 & 3 \\
\hline 1985 & & & 23,28 & 28 & 1 \\
\hline 1986 & & & $17,22,18$ & 20,28 & \\
\hline 1987 & 43 & 30 & 24,29 & & 1 \\
\hline 1988 & & 35 & 29 & & \\
\hline 1989 & & 51 & 24,26 & & \\
\hline 1990 & & 31,51 & 22,27 & & 6 \\
\hline 1991 & & 34,51 & 27 & & 49 \\
\hline 1992 & 44 & $32,34,37,51$ & 27 & & 15 \\
\hline 1993 & 46 & $32,34,51$ & 25,27 & & 6 \\
\hline 1994 & 46 & $34,50,51$ & 25,27 & 52 & $6,8,9$ \\
\hline 1995 & 46 & 34,51 & 25,27 & 52 & $4,6,7,11,14$ \\
\hline 1996 & 46 & 34,38 & 25 & 52 & $11,12,14$ \\
\hline 1997 & 46,47 & 34,40 & & 52 & $5,10,14$ \\
\hline 1998 & 46 & $33,34,40,41$ & & 52 & 14 \\
\hline 1999 & 46 & $33,34,40$ & & 52 & 14 \\
\hline 2000 & & $33,34,36,40,41$ & & 52 & 11 \\
\hline 2001 & & $34,39,40$ & & 52 & \\
\hline 2002 & & 34 & & 52 & \\
\hline
\end{tabular}

*Studies had to have had a dietary sample size $>15$, and had to have been conducted such that fish would have been adequately detected. Entries in cells refer to the applicable diet study; see numbered entries in the literature cited in the Appendix 1. 


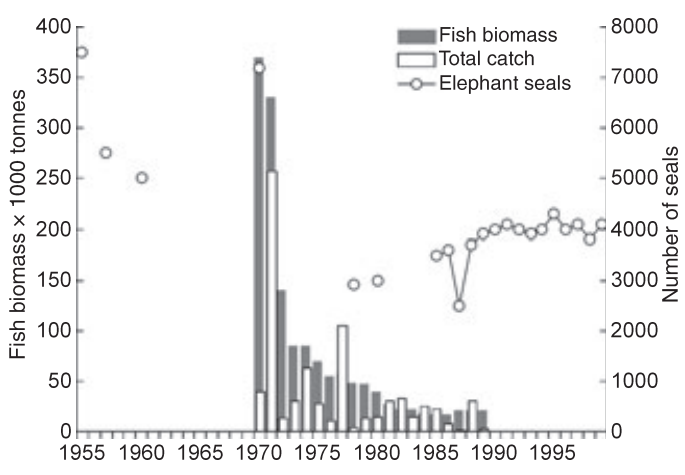

Figure 3 The population trajectory of elephant seals at Kerguelen Island in the midst of FAO Subarea 58.5 (from Weimerskirch et al. 2003), compared to the fish stock size and commercial take for FAO Divisions 58.5.1 and 58.5.2 (from Kock 1992), considering just the commercially caught species found in the seals' diet. Between 1958 and 1964, 12000 seals were killed under license (Kock 2007), which explains the decline and recovery during that period.

seals; Slip (1997) modified a presence/absence technique of Laws (1960) and estimated that fish once contributed $45 \%$ to the Scotia Sea diet. In any case, almost all studies of this species' diet have been conducted after its populations had declined (mid1980s: Table 2), and all were conducted well after fish were severely depleted in the SO (Figs 1, 3 and 4). Nevertheless, this seal is known to take several fish species that were or are still commercially exploited, as well as myctophids (Table 3). Elephant seals prey on toothfish more than do other species in this review, and given their size and foraging depth, they could easily take adult fish, a far more cost-effective catch than tiny myctophids. If, like Weddell seals Leptonychotes weddellii, elephant seals avoid eating the bony heads of adult toothfish (see Ainley et al. 2004 in Appendix 1), this would be one more factor that would reduce the apparent importance of this fish in the seals' diet (no otoliths ingested; cf. Goldsworthy et al. 2001).

Studies of the foraging behaviour of this species are similarly confined to the mid-1980s and later, when satellite telemetry came into use. With adult males travelling farthest away, and juveniles the least, elephant seals seek insular and continental shelf breaks, as well as sea mounts in mid-ocean, where foraging depths are as deep as $1000 \mathrm{~m}$ (McConnell et al. 1992, 2002; Jonker and Bester 1998; Van den Hoff et al. 2002; Hindell et al. 2003; Bailleul et al. 2007). Juveniles, especially, remain for long periods over shelves and shelfbreaks, where most commercial fishing takes/took place. An elegant body of demographic research and modelling points to the survival of juveniles as key to the dynamics of southern elephant seal populations (Pistorius et al. 1999a,b; Bradshaw et al. 2002; Pistorius and Bester 2002; McMahon et al. 2003, 2005a).

The population decline at Crozet Island (Fig. 4) closely tracks the decline in fish catch in the region, with decreasing steps following surges in the catch $(r=0.485, P=0.009$; no VPA estimate available). In a multiple variable correlation, both climate, i.e. air temperature $\left(r_{\mathrm{s}}=-0.668\right.$,

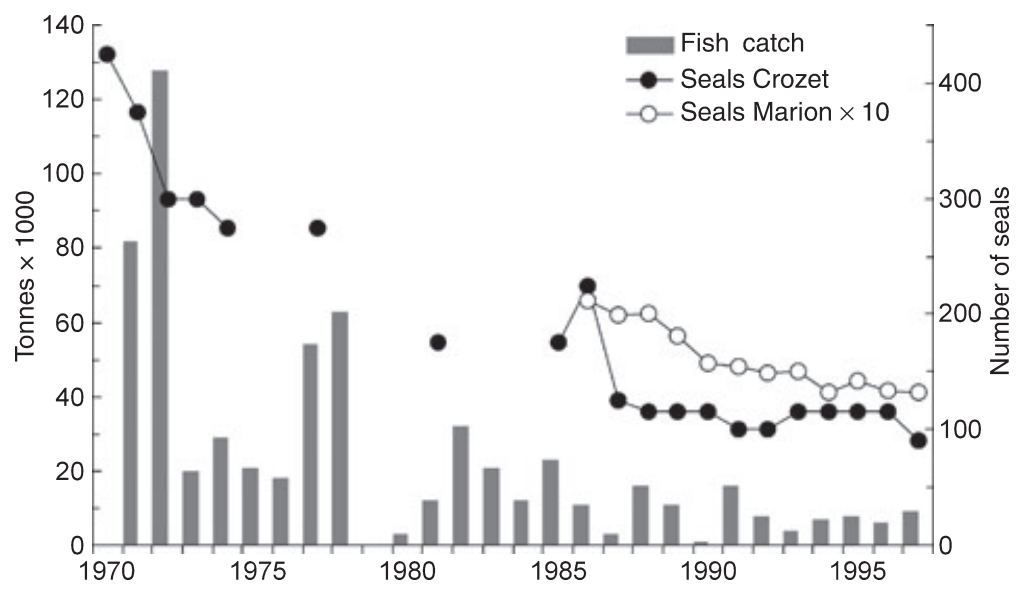

Figure 4 The population trajectory of elephant seals at Crozet Island, in the midst of FAO Subarea 58.7 (from Weimerskirch et al. 2003), and Marion Island, in the midst of FAO Subarea 58.6 (from Pistorius et al. 1999b), compared to the commercial take (FAO Subarea 58.7 and 58.6; fish data from Kock 1992; CCAMLR 2005f,g) of fish species found in the seals' diet. 
Table 3 Species of commercially taken fish (from Kock 1992) found in the diets of predators from Heard, Kerguelen, Crozet, Marion, South Georgia, South Shetland and South Orkney islands.*

\begin{tabular}{llcccc}
\hline & $\begin{array}{l}\text { Southern } \\
\text { elephant seal }\end{array}$ & $\begin{array}{l}\text { Antarctic } \\
\text { fur seal }\end{array}$ & $\begin{array}{l}\text { Gentoo } \\
\text { penguin }\end{array}$ & $\begin{array}{l}\text { Macaroni } \\
\text { penguin }\end{array}$ & $\begin{array}{l}\text { Imperial } \\
\text { cormorant }\end{array}$ \\
\hline $\begin{array}{l}\text { Dissostichus eleginoides } \\
\text { Champsocephalus gunnari }\end{array}$ & 17 & 3 & 10 & $\mathrm{X}$ & $\mathrm{X}$ \\
$\begin{array}{l}\text { Notothenia rossii } \\
\text { Patagonotothen guntheri }\end{array}$ & $\mathrm{X}$ & 84 & 31 & 27 & 8 \\
Gobionotothen gibberifrons & 12 & 2 & 6 & 4 & 71 \\
$\begin{array}{l}\text { Pseudochaenichthys georgianus } \\
\text { Chaenocephalus aceratus }\end{array}$ & 5 & $\mathrm{X}$ & 50 & & 80 \\
Lepidonotothen squamifrons & 6 & $\mathrm{X}$ & & & $\mathrm{X}$ \\
Channichthys rhinoceratus & $\mathrm{X}$ & 29 & 51 & $\mathrm{X}$ & 1 \\
Myctophids & 75 & 1 & 12 & 40 & 100 \\
Fish & 77 & 100 & 15 & 80 & \\
\hline
\end{tabular}

*Numbers indicate the maximum value for frequency of occurrence (\%) in the diet among existing studies. Frequency of occurrence was the only metric common to the large majority of diet studies; if no such value is available, an ' $X$ ' is entered. See Table 2 for the references from which these data were obtained.

$P<0.001)$, and fish catch $\left(r_{\mathrm{s}}=0.498, P<0.02\right)$ correlated with seal numbers. The multivariate relationship of seals to fish biomass and climate at Kerguelen had a similar outcome for air temperature $\left(r_{\mathrm{s}}=-0.661, P<0.001\right)$ and fish biomass $\left(r_{\mathrm{s}}=0.481, P<0.05\right.$; Fig. 3$)$. Considered in another way, Kerguelen elephant seal abundance 1955-1970, i.e. up to the advent of industrial fishing, averaged much higher (6300, $95 \%$ CI $=1238)$ than subsequently $(3729,95 \%$ $\mathrm{CI}=124 ; P<0.01)$, despite even the direct commercial take of Kerguelen elephant seals between 1958 and 1964 (Kock 2007). A major downward step in seal numbers occurred just after the major fish extraction. At Marion Island, with an especially short time series that began long after fish were severely depleted, the relationship of seals to fish catch followed a similar pattern to the above ( $r=0.835, P<0.001$; Fig. 4). Finally, at Anvers Island, on the northwestern Antarctic Peninsula and considering that this is not a sea-ice associated species, adult and subadult elephant seals increased until about 1990 as sea-ice disappeared (Siniff et al. 2008) but, subsequently, beginning a few years after the fish catch and biomass dropped off, the seal population began to decline despite sea-ice presence continuing on a downward trend.

\section{Antarctic fur seal}

The Antarctic fur seal population was severely reduced during historical times, as noted above. It has recovered in many areas and is still increasing in most others [Scientific Committee for Antarctic Research (SCAR) 2006]. As with population growth, the fur seals' diet varies spatially and temporally. In the Scotia Sea region, krill is important during the summer breeding season (Reid and Croxall 2001) but this is not the case elsewhere where they principally feed on fish (summarized in Green 2006; also see Guinet et al. 1996; Lea et al. 2006). In the Scotia Sea region, fish become more prevalent in the diet during winter (Reid 1995). Little is known of the Antarctic fur seals' diet before 1987 (Table 2), but juveniles of most commercially exploited fish species (historically and/or currently) are included in the present-day diet, especially $N$. rossii and $C$. gunnari; myctophids dominate the diet among seals in regions other than the Scotia Sea (Table 2). The insular and continental shelfbreaks and slopes, also targeted by fisheries, are the principle foraging habitat of this species, as determined by satellite tracking in recent decades (Boyd et al. 1994; McCafferty et al. 1998; Lea et al. 2006).

While Antarctic fur seal populations are stable or still increasing in most areas, at South Georgia and some areas at the southern periphery of the range just south of the South Shetland Islands, numbers have peaked and now are declining. The decline in fur seals at South Georgia, subsequent to fish depletion in the region (Figs 1 and 5), is positively related to krill abundance $(r=0.880, P<0.001)$. Reid et al. (2006) pointed out the link between fish 


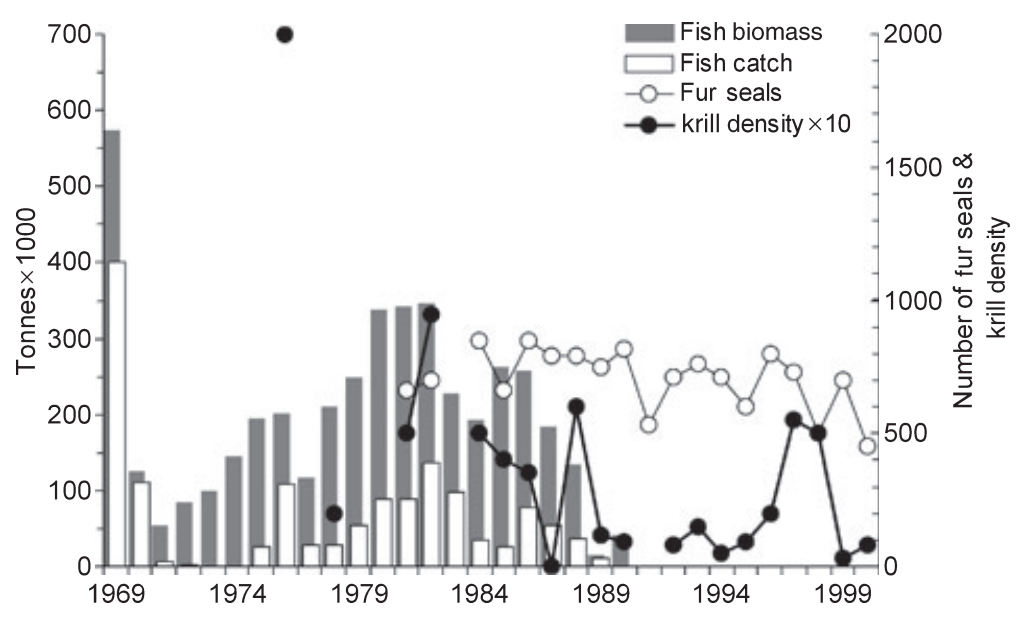

Figure 5 The population trajectory of fur seals at Bird Island, South Georgia (from Reid and Croxall 2001) in the midst of FAO Subarea 48.2, compared to the fish stock size and commercial take of fish in FAO Subareas 48.2 and 48.3 (fish data from Kock 1992), for species found in the fur seals' diet. Also shown is the density of krill (number $\mathrm{m}^{-2}$ ) in the Scotia Sea region (from Atkinson et al. 2004).

species present in Antarctic fur seal diet vs. fishery depletion; i.e. around South Georgia and the South Shetland Islands, fishery-depleted shelf species have disappeared from the diet. However, presently no relationship to fish biomass is apparent in the data we presented $(r=0.079)$; this species appears to have been able to prey-switch to krill, at least in areas where krill is found in high abundance, i.e. the Scotia Sea.

\section{Gentoo penguin}

This penguin species has been declining in all parts of its range during the past 20 years (Woehler et al.
2001; Crawford et al. 2003a; Lescroël and Bost 2006; Woehler 2006; Hinke et al. 2007), with one exception. That exception is the southern portion of FAO Area 48, where disappearing sea-ice is allowing southward invasion of very small numbers of this ice-avoiding species (Ducklow et al. 2007). Gentoo penguin numbers in newly colonized areas of Anvers Island and vicinity, to the south of the South Shetlands, are increasing but in the South Shetlands themselves established populations are slowly declining (Hinke et al. 2007). Still further north in FAO Area 48, on the basis of the next longest time series of population size, that from

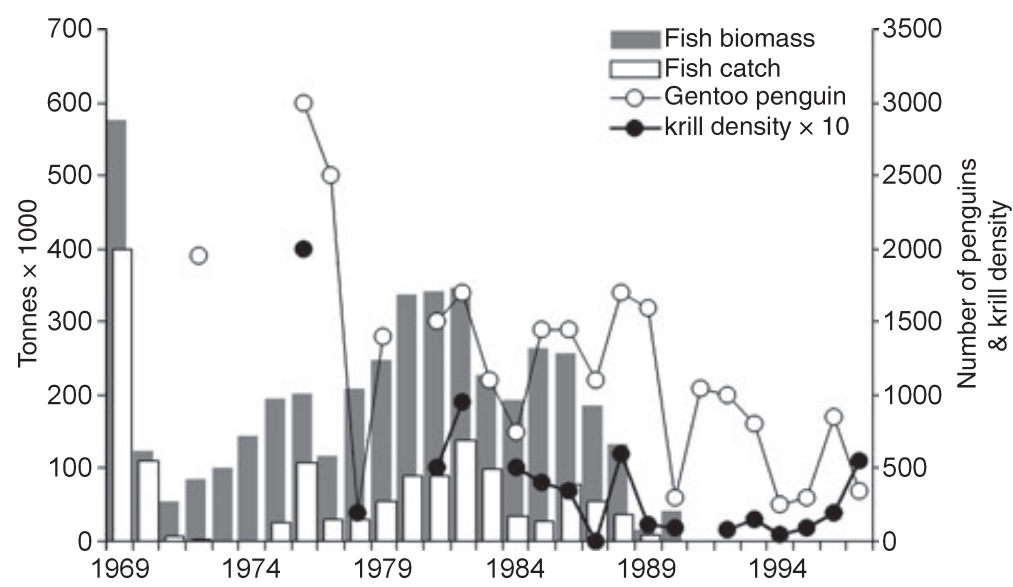

Figure 6 The population trajectory of gentoo penguins at Bird Island, South Georgia (from Woehler et al. 2001) in the midst of FAO Subarea 48.3, compared to the fish stock size and commercial take of fish species in FAO Subareas 48.2 and 48.3 (fish data from Kock 1992), using only those found in the penguins' diet. Shown also is the density of krill (number $\mathrm{m}^{-2}$ ) in the Scotia Sea region (from Atkinson et al. 2004). 
South Georgia, the species population has been declining more rapidly (Fig. 6). The same is true for Marion Island where the time series began only in 1994, but shows a gradual $40 \%$ decline to 2002 . A few counts in the 1960-1970s were equivalent to that of 1994 but an isolated 1984 count, during the major 1983-84 El Niño, was lower than the 1994 count (Crawford et al. 2003a).

Gentoo penguins at most locations prey principally on fish, including juveniles of the major fished species (Fig. 2, Table 3), with krill now more prevalent in the diet in the Scotia Sea. This penguin forages principally over shelf and slope waters (Lescroël et al. 2004; Cherel and Hobson 2007), i.e. areas targeted by the fisheries under discussion. During the period 1978-1988, the penguins' population at South Georgia closely tracked fish biomass $(r=0.381, P=0.021)$, but with the final removal of fish and closure of the fishery, the relationship of course dissolved due to a lack of data. With fish stocks severely depleted and then effectively removed from the Scotia Shelf ecosystem, the gentoo penguin population has been tracking krill abundance $(r=0.498$, $P=0.03$; see also Hinke et al. 2007 for South Shetland Islands).

As with the seals, above, appropriate diet studies for this penguin species were completed only after demersal fish were depleted but nevertheless show the importance to this penguin of the juveniles of the fished species (Tables 2 and 3). CCAMLR did not ban trawling in the region until 1990 (Kock 1992).
Thus, in earlier years, fish species that are prey for gentoo penguins, even if not commercially targeted, could well have been negatively affected as by-catch, as seems to have been the case for imperial cormorant (see below).

\section{Macaroni penguin}

This penguin species is declining throughout its range (Woehler et al. 2001; Crawford et al. 2003b). Only one long-term record of its population overlaps the fishing record, unfortunately, and that is from Bird Island, South Georgia (Fig. 7). After initially increasing in modern times, macaroni penguin numbers began to decline in the mid-1980s, a few years after the second crash in biomass of fish (see also Fig. 1). No data are available on numbers of penguins to overlap the first, larger crash in fish stocks, but during the period when penguin numbers are available, trends are strongly related to the level of fish biomass $(r=0.809 ; P=0.001)$. In these years, population variation is also related to that of krill density $(r=0.482, P=0.059)$. At Marion Island, numbers of macaroni penguins have declined by $18 \%$ since 1994 , the beginning of the population time series there (Crawford et al. 2003b).

Classified by many researchers in recent years as a 'krill predator', like the fur seals of the Scotia Sea, macaroni penguins prey appreciably on fish, including juveniles of commercially exploited species (Table 3). In the Scotia Sea region, this penguin forages regularly in waters overlying the shelf and slope, again as noted by modern satellite tracking

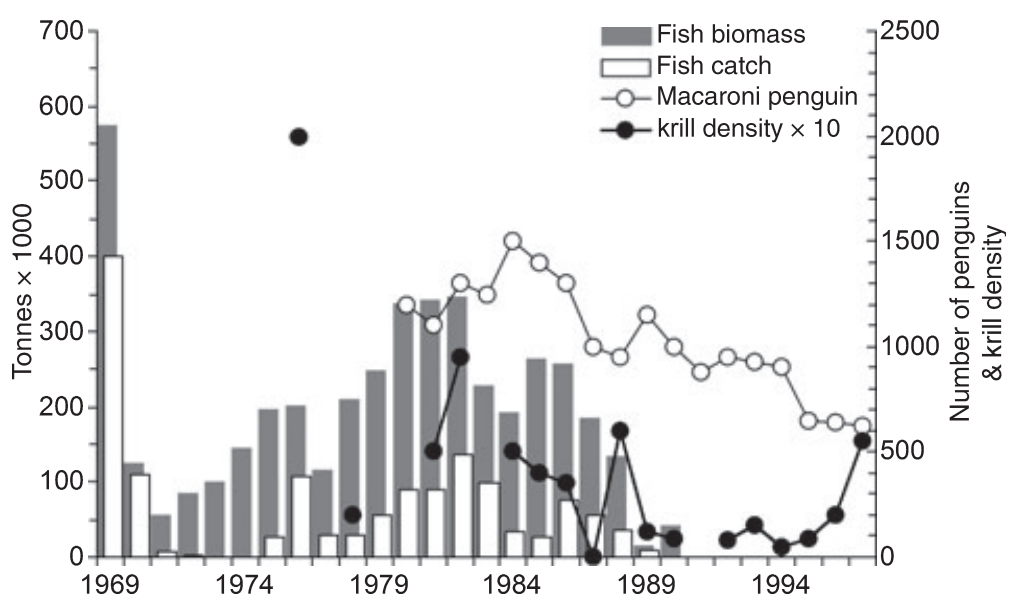

Figure 7 The population trajectory of macaroni penguins at Bird Island, South Georgia (from Woehler et al. 2001), compared to, in FAO Subareas 48.2 and 48.3, the fish stock size and commercial take of species found in the penguins' diet (fish data from Kock 1992), as well as to the density of krill (number $\mathrm{m}^{-2}$ ) in the Scotia Sea region (from Atkinson et al. 2004). 
(Barlow and Croxall 2002), i.e. areas targeted by the historical fishery. Although we did not include the study by Croxall and Furse (1990) in our summary (Table 2) because the sample size was low, $63 \%$ of the diet in the South Shetland Islands at the time of sampling (1976, i.e. 2 years prior to initiation of industrial fishing) was composed of fish (species unspecified). At Heard Island, fish are much more prevalent in the diet than at South Georgia, contributing up to $46 \%$ by mass (Klages et al. 1989); at Marion, they contribute up to $52 \%$ by mass (Crawford et al. 2003b). At the latter, chick fledging mass, important for subsequent survival, varies directly with the proportion of fish (species unspecified) in the diet (Crawford et al. 2003b). Myctophids are now very important to this species.

\section{Imperial cormorant}

The longest time series tracking population trends for the various subspecies or races of this piscivorous bird is that at Duthoit Point, South Shetland Islands, 1990-2004 (Casaux and Barrera-Oro 2006). This time series is not long enough to overlap with pre-fished stocks. This bird preys on small fish caught in shelf waters (Casaux and Barrera-Oro 1993, Casaux and Ramón 2002, Woehler 2006). Populations are clearly declining in both the South Shetland Islands and adjacent Antarctic Peninsula; the decrease began in the mid1980s (Green et al. 1998; Naveen et al. 2000, Casaux and Barrera-Oro 2006), following the final loss of fish from the ecosystem (Fig. 1). Few population assessments have been made elsewhere; those at Heard Island have been too sporadic to indicate any trends (Woehler 2006). These birds prey significantly on the juveniles of commercially extracted species, as well as others that would have been caught as by-catch by trawlers (Tables 1-3).

The declining population trend in the vicinity of the South Shetlands has already been tied to reduced availability of hitherto commercially caught forage fish (Casaux and Baroni 2002; Casaux and Barrera-Oro 2006). As a consequence, shags have concentrated their predation pressure on Notothenia coriiceps and Harpagifer antarcticus. Notothenia coriiceps is a K-selected species exhibiting strong site fidelity, which makes it highly vulnerable to predation pressure, confirmed experimentally in the field (Casaux and Barrera-Oro 2002). Adding to the shags' problems, $H$. antarcticus is a small-sized, cryptic species that lives sheltered under rocks. Thus, without the mid-water presence of notothe- niid juveniles of fished species, the reduction of $N$. coriiceps by the shags through the breeding season and the higher effort required to capture $H$. antarcticus likely resulted in a decrease in foraging efficiency in shags and a subsequent adverse population effect.

\section{Discussion}

\section{General thoughts}

There remains much conjecture over the response of the AME to the almost complete removal of whales from many areas during the 1950-1960s, essentially because the monitoring of population sizes and investigation of trophic roles of other components of the ecosystem did not get underway until well after the whales were gone. Only proxy variables have allowed any insight at all into how the ecosystem may have responded (summarized most recently in Ballance et al. 2006; see also Laws 1977a,b; Croxall et al. 1988a; Emslie and Patterson 2007). In this paper, we speculate on the response of certain parts of the AME to the mass removal of finfish that followed closely on the heels of the whale extraction. Most of the commercial fishery was intense and short-lived, with stocks of adults plummeting in many cases to $5-10 \%$ of former size (Kock 1994; and see figures herein), due to annual takes that often equalled or exceeded initial estimates of species' biomass (Kock 1992). Despite later area closures for the purposes of fish-stock recovery, few populations have recovered and some are still declining. Even recovering stocks show little potential for renewed commercial exploitation (Kock 1998; Barrera-Oro et al. 2000; Jones et al. 2000; CCAMLR 2004, 2007b; Barrera-Oro and Marschoff 2007). Given this pattern, it is likely that from the perspective of Antarctic fish predators, these fisheries removed ecologically significant quantities of prey from the system and, in particular, removed prey that existed close to breeding colonies. Indeed, this extraction, in our opinion, explains at least in part the ecosystem regime shifts described by Reid and Croxall (2001) for the Scotia Sea and by Weimerskirch et al. (2003) for the Indian Ocean sector during the mid-1980s. That latter regime shift is out of phase with the climate-driven, SO-wide shifts of the mid-1970s and late 1980s to early 1990s that are related to the SAM (cf. Ainley et al. 2005; Jenouvrier et al. 2005; Stammerjohn et al. 2008). 
Alteration in prey availability affects predator population growth in a variety of ways, e.g. breeding success and recruitment of subadults into the populations are affected. Similar scenarios have been thoroughly documented many times in other parts of the world's oceans, e.g. for marine birds in the Peru Current (Murphy 1981; Tovar et al. 1987), North Sea (Furness 2002; Oro and Furness 2002), Benguela Current (Crawford 2004, 2007), Baltic Sea (Österblom et al. 2006) and California Current (Field et al. 2007), and therefore we do not discuss in detail here the mechanisms by which SO predator survival would have been affected by wholesale removal of their fish prey. However, the fact that no modern-day, state-of-the-art investigations of the diets of predators occurred before the fish loss, and that virtually all were completed a decade later (Table 2), shows why one must view with great caution any conclusions that finfish fisheries had little effect on explaining predator population trajectories in the SO. While a number of authors have suggested that depletion of fish has been critically important (Pascal 1985; Barrera-Oro et al. 2000; Casaux and Barrera-Oro 2006), others have concluded otherwise based on the idea that diets do not currently contain much in the way of commercial fish species (McMahon et al. 2005b). Most authors these days confine their attention to climate change and/or krill as key to understanding the AME and predator-prey dynamics (Constable 2001; Croxall and Nicol 2004; Nicol 2005; Smetacek and Nicol 2005; Ducklow et al. 2007; Murphy et al. 2007). Why the potential for trophic cascades linked to this fish extraction heretofore has not been given more critical attention is perplexing (Ainley et al. 2007; cf. Scheffer et al. 2005).

While changing climate has indisputably had important effects on the AME (Atkinson et al. 2004; Ducklow et al. 2007; Murphy et al. 2007), a finding also confirmed in this paper, so too it seems has fish extraction been important. In fact, the major fish extraction described here occurred just before the SAM entered into the positive phase from which it has not since reverted. The SAM profoundly influences the SO climate (Stammerjohn et al. 2008) and thus certainly affects its ecosystems. Before the mid1970s, the SAM oscillated on a decadal scale between its two modes and in all likelihood the food web compensated accordingly. The fact that the SAM has become 'stuck' in its current mode may have made finfish populations even more vulnerable to the effects of exploitation (see below).
In addition, whether or not extensive invasions of the northern SO by sub-Antarctic fish species, e.g. the southern blue whiting Micromesistius australis in the Scotia Sea (Matthews 1978; see also below), were also a result of the SAM (or, as suggested by Matthews, a consequence of whale loss) is a question that may never be answered. That stock is severely depleted (FAO 2005: Southwest Atlantic), and should it partially recover it is likely that fishing pressure would be renewed, consistent with the ways of fisheries worldwide.

In regard to climate oscillations, lessons learned from the more accessible - and therefore more intensively studied - groundfish of the California Current clearly apply to SO nototheniids. Many of these fish provide an important supply of juveniles as forage for top predators (Lenarz 1980; Ainley et al. 1993; Field et al. 2007). As with the SAM, the PDO has become mostly 'stuck' since the 1970s, in its case in its warm phase (Peterson and Schwing 2003; Hooff and Peterson 2006). California Current groundfish, with their K-selected life-history strategies, are, like the nototheniids, highly vulnerable to intensive fishing (Pauly et al. 2005; Cheung et al. 2007). According to Steve Ralston (Groundfish Analysis Team Leader, US National Marine Fisheries Service, in litt, 28 June 2007), the allowable catch rate for California Current rockfish (Sebastes spp.) was initially based on the conventional wisdom derived from experience with many such stocks worldwide and was designed to produce no worse than a reduction to $75 \%$ of maximum sustainable yield (based on an $\mathrm{F} 35 \%$ fishing mortality rate reduction of lifetime egg production). However, that wisdom proved to be wrong when applied to the rockfish stocks, which during the 1980-1990s (when fishing intensity increased) were found to have unexpectedly low productivity, with virtually no surplus production (Clark 2002). At that time, juvenile rockfish were major components in the diet of many predatory fish, marine mammals and birds (Lenarz 1980). The consequence of rockfish K-selected life-history parameters, pre-fishing, had been a pronounced build-up in stock size, leading to the impression of a productive resource. The longevity of Sebastes is now seen to be an adaptation to bet-hedge reproduction over extended periods of poor reproductive success, as for instance during the warm phase of the PDO. What this means is that rockfish stocks (and other K-selected fish) can undergo low-frequency variation in population size attributable to decadal periods of favourable and 
unfavourable reproductive success. When a stock naturally fluctuates in abundance over a range of three to four times, it becomes problematic to designate an effective biomass target under fishing (Dorn 2002; Ralston 2002). The same seems to apply to SO nototheniids (Pauly et al. 2005; Cheung et al. 2007), the stocks of which, like rockfish, are dependent for stability on infrequent strong year classes, especially those produced during favourable climate regimes (Kock 1992).

\section{A perspective on the food web structure of the SO}

Like the larger eastern boundary currents - the Benguela and Peru/Humboldt currents - the SO also has generally directional circulation (although eastward, as opposed to equatorward in those boundary currents), narrow continental shelves and is affected strongly by upwelling along its continental margin - the so-called Antarctic Slope Front (Ainley and Jacobs 1981; Jacobs 1991; Hofmann 2007). Like the eastern boundary currents, the SO has some smaller-scale structure from embedded currents with accompanying fronts, e.g. the Antarctic Circumpolar Current and its southern boundary (Orsi et al. 1995; Tynan 1998; Nicol et al. 2000) and near-coast gyres and eddies (Nicol 2005). The SO is also spatially equivalent to the larger boundary systems (see Longhurst and Pauly 1987).

The pelagic portions of the SO constitute the major portion of the AME. However, not to be discounted are the extensive insular-shelf/bankcentred food webs (including seamounts), which although patchily distributed, somewhat like beads in a necklace, encircle the northern periphery of the AME (Fig. 2). These shelves and banks are not insignificant in the workings of the AME because, for instance, elephant seals from these sites (plus the Macquarie Island colony) currently range over much of the ice-free SO in seeking their preferred foraging habitat; the fur seal, and to a lesser extent the other species reviewed, cover significant portions of the AME as well. This extensive predator sampling of the SO should not be hard to envision, because, as noted by Longhurst and Pauly (1987), the waters south of the Antarctic Polar Front occupy no more space than the triangle formed between Madagascar, the tip of India and western Australia, or roughly the size of Europe. Thus, Mercator projections notwithstanding, the SO is a relatively small body of water.
These insular shelves, banks and sea mounts, as we have documented, recently possessed food webs in which fish played a major role, at least as prey, but likely also as predators. Species such as mackerel icefish and marbled notothenia, when abundant in the past, were likely important predators of krill (cf. Reid 1995; Everson et al. 1999; Kock and Jones 2005), as were other fish species, like blue whiting (above), that made major migrations from sub-Antarctic areas into northern portions of the SO as seasonal predators (Laws 1977b; Everson 1984; Kock 1992). With these insular food webs now altered, it is also possible that, today, the predators we review seek prey at greater distances than they did not all that long ago.

In addition to the insular shelves, ringing the southern periphery of the AME is the continent's neritic ecosystem and, as noted, it is generally narrow (although it has not always been so in the evolutionary scale of Antarctic fishes and the AME; Eastman 1995). In its food web, fish are recognized even now as playing central trophic roles as both predators and prey. Members of this food web include Antarctic toothfish, silverfish Pleuragramma antarcticum, Weddell seals, emperor penguins Aptenodytes forsteri, Adélie penguins, minke whales Balaneoptera bonarensis and type-C killer whales (summarized in Ainley et al. 2006). In the past, even humpbacks whales Megaptera novaeangliae apparently also fed to an appreciable degree on fish, rather than krill, in this shelf ecosystem (Laws 1977a), just as they do in neritic ecosystems elsewhere. The populations of these whales are increasing rapidly in the Antarctic Peninsula region (Branch 2006), and thus it is important to assess the degree to which they may be affecting population trends among potential competitors such as penguins (cf. Hinke et al. 2007).

We do not dispute the importance of krill in the workings of (much of) the AME (see recent summaries in Nicol 2005; Smetacek and Nicol 2005; Siegel 2005; Ducklow et al. 2007; Murphy et al. 2007), but based on the spatial and historical context of our analysis, we disagree with the contention of Nicol et al. (2007) that fish were never an important part of this system (see further confirmation in Hill et al. 2007). We further believe that this contention, at least in part, must have been one based on shifting baselines. The latter are both real and in the perceptions of practicing ecologists; that is, marine biologists tend to see as normal the population levels and ecosystem states that existed 
at the start of their careers, with subsequent changes evaluated against these attenuated norms. Thus, radical ecological changes from just a few decades earlier, before each generation began its respective work, are at best under-appreciated and at worst unnoticed (Pauly 1995; Schrope 2006). Finally, it is apparent even now that a group of fishes, the Myctophidae, is critically important to many SO predators (Table 3), with any fishery for these potentially having further negative consequences for SO food webs (see also Goldsworthy et al. 2001).

Many SO ecologists may well argue, at least initially, that only Antarctic krill occur in numbers that could compare with, for example, the (past) stocks of anchovies Engraulis spp. or sardines Sardinops spp. of the Peru and Benguela systems. On the other hand, the predators of the SO's insular and northern continental shelves once relied on stocks of benthic finfish to provide an abundant source of food. This is in accord with the comments of Gon and Heemstra (1990), who described how species such as mackerel icefish supplied important forage (juvenile fish) to pelagic-feeding top predators despite the adults' demersal life style and relatively 'local' spawning grounds. These predators, judging from the size classes of prey in presentday diets (North et al. 1983; Barrera-Oro et al. 2000; Reid et al. 2005), heavily exploited the juvenile and 1- to 2-year fish, with the bottomdwelling adults generally being little affected (except perhaps by elephant seals). Indeed, the movements and annual cycles of adult nototheniids may well have evolved to avoid predation by top predators (Everson 1970). Therefore, in such a system where the secondary and tertiary production is in its mid- to upper-water column, in the form of krill, myctophids and juvenile demersal fish, high numbers of predators could exist, including fish, squid, mammals and birds (see for example, Bradford-Grieve et al. 2003; Overholtz and Link 2007), and these predators could switch prey depending on availability. Having a choice among a variety of meso- to epipelagic prey is important because, for example, a gentoo penguin needs to catch just one fish every third dive compared to 15 adult krill on every dive in order to be successful (Croxall et al. 1988b); for fur seals, the energetic cost of foraging for subadult $C$. gunnari is many times lower than for much smaller myctophids (Lea et al. 2006). Now, with demersal fish breeding stocks vastly curtailed, the populations of middle and top predators (except perhaps Antarctic fur seal) no longer have a prey-switching option and have been progressing towards a much lower trophic equilibrium where they closely track krill abundance (Fraser and Hofmann 2003; Hinke et al. 2007; Murphy et al. 2007). Indeed, fish surveys or predator diets now clearly reflect the low abundance of the historically heavily fished species (North et al. 1983; Kock 1998; Barrera-Oro et al. 2000; Jones et al. 2000; Reid et al. 2006; see also Trites et al. 1999). Moreover, with reduced stocks and a reduced set of choices, predators can now more easily deplete their fish (or krill) resource, as suggested in the case of the fur seals, imperial shags and mackerel icefish described by Everson et al. (1999; see also Agnew et al. 1998; Casaux and Barrera-Oro 2002; Reid et al. 2005, 2006).

Beyond affecting the population trajectories of the major avian and mammalian 'indicator species' (as used by CEMP) considered here, the loss of groundfish stocks from the AME could well have greater consequences. For instance, as a number of SO commercially extracted fish species are important salp predators (Casaux et al. 1990; Kock 1992; Pakhomov 1997; Barrera-Oro 2003; Bushula et al. 2005), this loss could conceivably be playing a role in the rise of salps in the Scotia/Weddell portion of the SO (cf. Atkinson et al. 2004; Ainley et al. 2007). The replacement of krill by salps is thus reminiscent of the recent takeover of heavily fished food webs by gelatinous organisms in the North Sea, Benguela Current, Black Sea, Bering Sea and elsewhere, as these nektonic organisms respond to decreased populations of their predators (Brierley et al. 2001; Mills 2001; Brodeur et al. 2002; Heymans et al. 2004; Xian et al. 2005; Lynam et al. 2006; Daskalov et al. 2007).

\section{Final thoughts}

Herein we have provided examples, using CEMP's 'indicator species', of the probable ecological consequences of historical depletion of the larger fish that were an important part of the food web for the SO's northern continental and insular shelves, suggesting that this major extraction compounded the ecosystem effects of the historical extraction of whales and later climate-related changes. How this food web, and even that of the larger AME, was once structured is beyond anyone's guess, as even the basic biology of these fish was learned only in 
the 1970s (and later), after most of their stocks were gone (Kock 1992; Eastman 1995). In many areas, the mid-trophic levels have effectively been reduced to just a few species, such as Antarctic krill and myctophid fish (Smetacek and Nicol 2005; Emslie and Patterson 2007; Hill et al. 2007). Gauging the true ecological role of the depleted demersal fish may now be beyond our research capability, unless of course food webs over significant areas are allowed to recover to whatever new stable state they might achieve (Frank et al. 2005; Worm et al. 2006; Overholtz and Link 2007).

\section{Acknowledgements}

Thanks to the efforts of CCAMLR and FAO, fish extraction in the SO is fairly well documented from its inception to the present, and thanks to the efforts of steadfast and sometimes courageous biologists, the trends in a few predator populations have been documented annually through most of the history of the SO fisheries. We also appreciate the counsel, comments and references supplied by G. Ballard, R. Casaux, J. Eastman, W. Fraser, K.-H. Kock, A. Lescroël, D. Pauly, S. Ralston, E. Woehler and four anonymous referees. K. Dugger kindly advised on statistics. DGA's effort was supported by National Science Foundation grant 0440643, while LKB's was funded by a Natural Sciences and Engineering Research Council post-graduate scholarship.

\section{References}

Note: see also Appendix 1.

Aebischer, N.J., Coulson, J.C. and Colebrook, J.M. (1990) Parallel long term trends across four marine trophic levels and weather. Nature 347, 753-755.

Agnew, D.J., Everson, I., Kirkwood, G.P. and Parkes, G.B. (1998) Towards the development of a management plan for the mackerel icefish (Champsocephalus gunnari) in Subarea 48.3. CCAMLR Science 5, 63-77.

Agnew, D., Pearce, J., Peatman, T., Pitcher, T.J. and Pramod, G. (2008) The Global Extent of Illegal Fishing. MRAG, London, UK, and FERR, Fisheries Centre, UBC, Vancouver, Canada.

Ainley, D.G. (2004) Acquiring a 'base datum of normality' for a marine ecosystem: the Ross Sea, Antarctica. CCAMLR Document WG-EMM-04/20, Hobart, 18 pp.

Ainley, D.G. and Divoky, G.J. (2001) Seabirds: effects of climate change. In: Encyclopedia of Ocean Sciences (eds J. Steele, S. Thorpe and K. Tarekian). Academic Press, London, pp. 54-65.
Ainley, D.G. and Jacobs, S.S. (1981) Affinity of seabirds for ocean and ice boundaries in the Antarctic. Deep-Sea Research 28A, 1173-1185.

Ainley, D.G., Sydeman, W.J., Parrish, R.H. and Lenarz, W.H. (1993) Oceanic factors influencing distribution of young rockfish (Sebastes) in central California: a predator's perspective. California Cooperative Oceanic Fisheries Investigations, Reports 34, 133-139.

Ainley, D.G., Clarke, E.D., Arrigo, K., Fraser, W.R., Kato, A., Barton, K.J. and Wilson, P.R. (2005) Decadal-scale changes in the climate and biota of the Pacific sector of the Southern Ocean, 1950s to the 1990s. Antarctic Science 17, 171-182.

Ainley, D., Toniolo, V., Ballard, G. et al. (2006) Managing ecosystem uncertainty: critical habitat and dietary overlap of top-predators in the Ross Sea. CCAMLR Document WG-EMM-06/29, Hobart, 15 pp.

Ainley, D.G., Ballard, G., Ackley, S. et al. (2007) Paradigm Lost, or is top-down forcing no longer significant in the Antarctic marine ecosystem? Antarctic Science 19, 283290.

Atkinson, A., Siegel, V., Pakhomov, E. and Rothery, P. (2004) Long-term decline in krill stock and increase in salps within the Southern Ocean. Nature 432, 100-103.

Australian Fisheries Management Authority (2007) Heard and McDonald Islands Fishery. Available at: http:// www.afma.gov.au/fisheries/antarctic/himi/at_a_glance. htm (accessed 27 June 2007).

Bailleul, F., Charrassin, J.-B., Ezraty, R., Girard-Ardhuin, F., McMahon, C.R., Field, I.C. and Guinet, C. (2007) Southern elephant seals from Kerguelen Islands confronted by Antarctic Sea ice. Changes in movements and in diving behaviour. Deep-Sea Research II 54, 343-355.

Ballance, L., Pitman, R.L., Hewitt, R.P., Siniff, D.B., Trivelpiece, W.Z., Clapham, P.J. and Brownell, R.L., Jr (2006) The removal of large whales from the Southern Ocean: evidence for long-term ecosystem effects? In: Whales, Whaling and Ocean Ecosystems (eds J.A. Estes, D.P. Demaster, D.F. Doak, T.E. Williams and R.L. Brownell, Jr). University of California Press, Berkeley, pp. 215-230. Barlow, K.E. and Croxall, J.P. (2002) Seasonal and interannual variation in foraging range and habitat of macaroni penguins Eudyptes chrysolophus at South Georgia. Marine Ecology Progress Series 232, 291-304.

Barrera-Oro, E. (2003) Analysis of dietary overlap in Antarctic fish (Notothenioidei) from the South Shetland Islands: no evidence of food competition. Polar Biology 26, 631-637.

Barrera-Oro, E.R. and Marschoff, E.R. (2007) Information on the status of fjord Notothenia rossii, Gobionotothen gibberifrons and Notothenia coriiceps in the lower South Shetland Islands, derived from the 2000-2006 monitoring program at Potter Cove. CCAMLR Science 14, 83-87. Barrera-Oro, E.R., Marschoff, E.R. and Casaux, R.J. (2000) Trends in relative abundance of fjord Notothenia rossii, Gobionotothen gibberifrons and Notothenia coriiceps at 
Potter Cove, South Shetland Islands, after commercial fishing in the area. CCAMLR Science 7, 43-52.

Beamish, R.J., Noakes, D.J., McFarlane, G.A., Klyashtorin, L., Ivanov, V.V. and Kurashov, V. (1999) The regime concept and natural trends in the production of Pacific salmon. Canadian Journal of Fisheries and Aquatic Science 56, 516-526.

Beaugrand, G., Reid, P.C., Ibanez, F., Lindley, J.A. and Edwards, M. (2002) Reorganization of North Atlantic marine copepod biodiversity and climate. Science $\mathbf{2 9 6}$, 1692-1694.

Beddington, J.R. and May, R.M. (1982) The harvesting of interacting species in a natural ecosystem. Scientific American November 1982, 62-69.

Bengtson, J.L. and Laws, R.M. (1985) Trends in crabeater seal age at maturity: an insight into Antarctic marine interactions. In: Antarctic Nutrient Cycles and Food Webs (eds W.R. Siegfried, P.R. Condy and R.M. Laws). Springer-Verlag, Berlin and Heidelberg, pp. 669-675.

Boyd, I.L., Arnould, J.P.Y., Barton, T. and Croxall, J.P. (1994) Foraging behaviour of Antarctic fur seals during periods of contrasting prey abundance. Journal of Animal Ecology 63, 703-713.

Bradford-Grieve, J.M., Probert, P.K., Nodder, S.D. et al. (2003) Pilot trophic model for subantarctic water over the Southern Plateau, New Zealand: a low biomass, high transfer efficiency system. Journal of Experimental Marine Biology and Ecology 289, 223-262.

Bradshaw, C.J.A., McMahon, C.R., Hindell, M.A., Pistorius, P.A. and Bester, M.N. (2002) Do southern elephant seals show density dependence in fecundity? Polar Biology $\mathbf{2 5}$, 650-655.

Branch, T.A. (2006) Humpback abundance south of $60^{\circ} \mathrm{S}$ from three completed sets of IDCR/SOWER circumpolar surveys. International Whaling Commission Paper SC/A06/HW6, 14 pp.

Brierley, A.S., Axelsen, B.E., Buecher, E., Sparks, C.A.J., Boyer, H. and Gibbons, M.J. (2001) Acoustic observations of jellyfish in the Namibian Benguela. Marine Ecology Progress Series 210, 55-66.

Brodeur, R.D., Sugisaki, H. and Hunt, G.L. Jr. (2002) Increases in jellyfish biomass in the Bering Sea: implications for the ecosystem. Marine Ecology Progress Series 233, 89-103.

Bushula, T., Pakhomov, E.A., Kaehler, S., Davis, S. and Kalin, R.M. (2005) Diet and daily ration of two nototheniid fish on the shelf of the sub-Antarctic Prince Edward Islands. Polar Biology 28, 585-593.

Casaux, R. and Baroni, A. (2002) Does fish prey size affect the foraging patterns and breeding output of the Antarctic Shag Phalacrocorax bransfieldensis? CCAMLR document WG-EMM-O2/04, Hobart, 12 pp.

Casaux, R. and Barrera-Oro, E. (1993) The diet of the blue-eyed shag, Phalacrocorax atriceps bransfieldensis at the West Antarctic Peninsula. Antarctic Science 5, 335-338.
Casaux, R. and Barrera-Oro, E. (2002) Effect of a shorebased sampling programme on Notothenia coriiceps populations. Antarctic Science 14, 221-224.

Casaux, R. and Barrera-Oro, E. (2006) Shags in Antarctica: their feeding behaviour and ecological role in the marine food web. Antarctic Science 18, 314.

Casaux, R. and Ramón, A. (2002) The diet of the South Georgia shag Phalacrocorax georgianus at the South Orkney Islands along five consecutive years. Polar Biology 25, 557-561.

Casaux, R.J., Mazzotta, A.S. and Barrera-Oro, E.R. (1990) Seasonal aspects of the biology and diet of nearshore nototheniid fish at Potter Cove, South Shetland Islands, Antarctica. Polar Biology 11, 63-72.

CCAMLR (2004) Assessment and Management Advice for Other Areas and Species in the Atlantic Ocean. CCAMLR Fishery Report. Available at: http://www.ccamlr.org/pu/ e/e_pubs/fr/drt.htm (accessed 1 August 2007).

CCAMLR (2005a) Fishery Report: Dissostichus eleginoides South Georgia (Subarea 48.3). CCAMLR Fishery Report. Available at: http://www.ccamlr.org/pu/e/e_pubs/fr/ drt.htm (accessed 11 May 2007).

CCAMLR (2005b) Fishery Report: Champsocephalus gunnari South Georgia (Subarea 48.3). CCAMLR Fishery Report. Available at: http://www.ccamlr.org/pu/e/e_pubs/fr/ drt.htm (accessed 11 May 2007).

CCAMLR (2005c) Fishery Report: Dissostichus eleginoides Kerguelen Islands (Division 58.5.1). CCAMLR Fishery Report. Available at: http://www.ccamlr.org/pu/e/e_ pubs/fr/drt.htm (accessed 11 May 2007).

CCAMLR (2005d) Fishery Report: Champsocephalus gunnari Heard Island (Division 58.5.2). CCAMLR Fishery Report. Available at: http://www.ccamlr.org/pu/e/e_pubs/fr/ drt.htm (accessed 11 May 2007).

CCAMLR (2005e) Fishery Report: Dissostichus eleginoides Heard Island (Division 58.5.2). CCAMLR Fishery Report. Available at: http://www.ccamlr.org/pu/e/e_pubs/fr/ drt.htm (accessed 11 May 2007).

CCAMLR (2005f) Fishery Report: Dissostichus eleginoides Crozet Island Inside the French EEZ (Subarea 58.6). CCAMLR Fishery Report. Available at: http://www. ccamlr.org/pu/e/e_pubs/fr/drt.htm (accessed 11 May 2007).

CCAMLR (2005g) Fishery Report: Dissostichus eleginoides Prince Edwards Islands South African EEZ (Subareas 58.6 and 58.7). CCAMLR Fishery Report. Available at: http://www.ccamlr.org/pu/e/e_pubs/fr/drt.htm (accessed 11 May 2007).

CCAMLR (2007a) CEMP Introduction. Available at: http://www.ccamlr.org/pu/E/sc/cemp/intro.htm (accessed 1 August 2007).

CCAMLR (2007b) Summary of Conservation Measures and Resolutions in Force 2006/07. CCAMLR Conservation Measures. Available at: http://www.ccamlr.org/pu/e/ e_pubs/cm/06-07/toc.htm (accessed 15 May 2007). 
CCAMLR (2007c) Fishery Reports. Available at: http://www.ccamlr.org/pu/e/e_pubs/fr/drt.htm (accessed August 2007) (accessed 15 May 2007).

Cherel, Y. and Hobson, K.A. (2007) Geographical variation in carbon stable isotope signatures of marine predators: a tool to investigate their foraging areas in the Southern Ocean. Marine Ecology Progress Series 329. 281-287.

Cheung, W., Watson, R., Morato, T., Pitcher, T. and Pauly, D. (2007) Change of intrinsic vulnerability in the global fish catch. Marine Ecology Progress Series 333, 1-12.

Clark, W.G. (2002) F35\% revisited ten years later. North American Journal of Fisheries Management 22 , 251-257.

Constable, A.J. (2001) The ecosystem approach to managing fisheries: achieving conservation objectives for predators of fished species. CCAMLR Science 8, 37-64.

Crawford, R.J.M. (2004) Accounting for food requirements of seabirds in fisheries management - the case of the South African purse-seine fishery. African Journal of Marine Science 26, 197-203.

Crawford, R.J.M. (2007) Food, fishing and seabirds in the Benguela upwelling system. Journal of Ornithology, 148 (Suppl 2), S253-S260.

Crawford, R.J.M., Cooper, J., Du Toit, M. et al. (2003a) Population and breeding of the gentoo penguin Pygoscelis papua at Marion Island, 1994/95-2002/03. African Journal of Marine Science 25, 463-474.

Crawford, R.J.M., Cooper, J. and Dyer, B.M. (2003b) Population of the macaroni penguin Eudyptes chrysolophus at Marion Island 1994/95-2002/03, with information on breeding and diet. African Journal of Marine Science 25, 475-486.

Croxall, J.P. (1992) Southern ocean environmental changes: effects on seabird, seal and whale populations. Philosophical Transactions of the Royal Society of London. Series B 338, 319-328.

Croxall, J.P. and Furse, J.R. (1990) Food of chinstrap penguins Pygoscelis antarctica and macaroni penguins Eudyptes chrysolophus at Elephant Island Group, South Shetland Islands. The Ibis 122, 237-245.

Croxall, J.P. and Nicol, S. (2004) Management of Southern Ocean fisheries: global forces and future sustainability. Antarctic Science 16, 569-584.

Croxall, J.P., McCann, T.S., Prince, P.A. and Rothery, P. (1988a) Reproductive performance of seabirds and seals at South Georgia and Signy Island, South Orkney Islands, 1976-1978: implications for Southern Ocean monitoring studies. In: Antarctic Ocean and Resources Variability (ed. D. Sahrhage). Springer-Verlag, Berlin, pp. 261-285.

Croxall, J.P., Davis, R.W. and O'Connell, M.J. (1988b) Diving patterns in relation to diet of Gentoo and Macaroni penguins at South Georgia. Condor 90, 157167.
Croxall, J.P., Trathan, P.N. and Murphy, E.J. (2002) Environmental change and Antarctic seabird populations. Science 297, 1510-1514.

Daskalov, G.M., Grishin, A.N., Rodionov, S. and Mihneva, V. (2007) Trophic cascades triggered by overfishing reveal possible mechanisms of ecosystem regime shifts. Proceedings of the National Academy of Sciences 104, 10518-10523.

Dorn, M.W. (2002) Advice on west coast rockfish harvest rates from Bayesian meta-analysis of stock-recruit relationships. North American Journal of Fisheries Management 22, 280-300.

Ducklow, H.W., Baker, K., Martinson, D.G. et al. (2007) Marine pelagic ecosystems: the West Antarctic Peninsula. Philosophical Transactions of the Royal Society of London. Series B 362, 67-94.

Duhamel, G., Gasco, P. and Davaine, P. (2005) Poissons des Îles Kerguelen et Crozet. Guide Régional de l'Océan Austral. Muséum National d'Histoire Naturelle, Paris.

Eastman, J.T. (1995) Antarctic Fish Biology: Evolution in a Unique Environment. Academic Press, San Diego, 322 pp.

Edwards, M. and Richardson, A.J. (2004) Impact of climate change on marine pelagic phenology and trophic mismatch. Nature 430, 881-884.

Emslie, S.D. and Patterson, W.P. (2007) Abrupt recent shift in $\delta^{13} \mathrm{C}$ and $\delta^{15} \mathrm{~N}$ values in Adelie penguin eggshell in Antarctica. Proceedings of the National Academy of Sciences 104, 1666-11669.

Everson, I. (1970) The population dynamics and energy budget of Notothenia neglecta Nybelin at Signy Island, South Orkney Islands. British Antarctic Survey Bulletin 23, 25-50.

Everson, I. (1984) Fish biology. In: Antarctic Ecology (ed. R.M. Laws). Academic Press, London, pp. 491-532.

Everson, I., Parkes, G., Kock, K.-H. and Boyd, I.L. (1999) Variation in standing stock of the mackerel icefish Champsocephalus gunnari at South Georgia. Journal of Applied Ecology 36, 591-603.

FAO (2007) Fisheries and Aquaculture Department: Statistics. Available at: http://www.fao.org/fi/website/ FIRetrieveAction.do?dom=topic\&fid=16003 (accessed 1 March 2008).

FAO (2005) Review of the State of the World Ocean Fishery Resources. In: FAO Technical Paper 457, Food and Agriculture Organization of the United Nations, Rome, 20 pp.

Field, J.C., Dick, E.J., Key, M. et al. (2007) Population dynamics of an unexploited rockfish (Sebastes jordani) in the California Current. In: Biology, Assessment, and Management of North Pacific Rockfishes, AK-SG-07-01. Alaska Sea Grant College Program, Seattle, pp. 451472 .

Frank, K.T., Petrie, B., Choi, J.S. and Leggett, W.C. (2005) Trophic cascades in a formerly cod-dominated ecosystem. Science 308, 1621-1623. 
Fraser, W.R. and Hofmann, E.E. (2003) A predator's perspective on causal links between climate change, physical forcing and ecosystem response. Marine Ecology Progress Series 265, 1-15.

Fraser, W.R., Trivelpiece, W.Z., Ainley, D.G. and Trivelpiece, S.G. (1992) Increases in Antarctic penguin populations: reduced competition with whales or a loss of sea ice due to environmental warming? Polar Biology 11, 525-531.

Furness, R.W. (2002) Management implications of interactions between fisheries and sandeel-dependent seabirds and seals in the North Sea. ICES Journal of Marine Science 59, 261-269.

Garibaldi, L. and Caddy, J.F. (2004) Depleted marine resources: an approach to quantification based on the FAO capture database. FAO Fisheries Circular, No. 1011. Food and Agriculture Organization, Rome, 32 pp.

Goldsworthy, S.D., He, X., Tuck, G.N., Lewis, M. and Williams, R. (2001) Trophic interactions between the Patagonian toothfish, its fishery, and seals and seabirds around Macquarie Island. Marine Ecology Progress Series 218, 283-302.

Gon, O. and Heemstra, P.C. (1990) Fishes of the Southern Ocean. J.L.B. Smith Institute of Ichthyology, Grahamstown, South Africa, $462 \mathrm{pp}$.

Green, K. (2006) Heard Island - the later ANARE years 1963-2001. In: Heard Island: Southern Ocean Sentinel (eds K. Green and E. Woehler). Surrey Beatty and Sons Pty. Ltd, Chipping Norton, pp. 231-253.

Green, K. and Burton, H.R. (1993) Comparison of the stomach contents of the southern elephant seal, Mirounga leonina, at Macquarie and Heard Islands. Marine Mammal Science 9, 10-22.

Green, K., Slip, D.J. and Moore, G.J. (1998) The take of fish species by seabirds and marine mammals in the Australian Fisheries Zone around Heard Island: the potential for competition with a commercial fishery. Polar Biology 20, 273-280.

Guinet, C., Cherel, Y., Ridoux, V. and Jouventin, P. (1996) Consumption of marine resources by seabirds and seals in Crozet and Kerguelen waters: changes in relation to consumer biomass 1962-85. Antarctic Science 8, 23-30.

Hare, S.R. and Mantua, N.J. (2000) Empirical evidence for North Pacific regime shifts in 1977 and 1989. Progress in Oceanography 47, 103-145.

Harvey, J.T. and Antonelis, G.A. (1994) Biases associated with non-lethal methods of determining the diet of northern elephant seals. Marine Mammal Science 10, 178-187.

Heymans, J.J., Shannon, L.J. and Jarre, A. (2004) Changes in the northern Benguela ecosystem over three decades: 1970s, 1980s, and 1990s. Ecological Modeling 172, 175-195.

Hill, S., Reid, K., Thorpe, S., Hinke, J. and Watters, G. (2007) A compilation of parameters for a krill-fishery- predator model of the Scotia Sea and Antarctic Peninsula. CCAMLR Science 14, 1-25.

Hindell, M.A., Slip, D.J. and Burton, H.R. (1994) Possible causes of the decline of southern elephant seal populations in the southern Pacific and southern Indian Oceans. In: Elephant Seals: Population Ecology, Behaviour, and Physiology (eds B.J. LeBoeuf and R.M. Laws). University of California Press, Berkeley, pp. 66-84.

Hindell, M.A., Bradshaw, C.J.A., Sumner, M.D., Michael, K.J. and Burton, H.R. (2003) Dispersal of female southern elephant seals and their prey consumption during the austral summer: relevance to management and oceanographic zones. Journal of Applied Ecology 40 , 703-715.

Hinke, J.T., Salwicka, K., Trivelpiece, S.G., Watters, G.M. and Trivelpiece, W.Z. (2007) Divergent responses of Pygoscelis penguins reveal a common environmental driver. Oecologia 153, 845-855.

Hofmann, E.E. (ed.) (2007) The Southern Ocean GLOBEC programme. GLOBEC Newsletter 13, 49-66.

Hooff, R.C. and Peterson, W.T. (2006) Copepod biodiversity as an indicator of changes in ocean and climate conditions of the northern California current ecosystem. Limnology and Oceanography 5, 2607-2620.

Jacobs, S.S. (1991) On the nature and significance of the Antarctic Slope Front. Marine Chemistry 35, 9-24.

Jenouvrier, S., Weimerskirch, H., Barbraud, C., Park, Y.-H. and Cazelles, B. (2005) Evidence of a shift in the cyclicity of Antarctic seabird dynamics linked to climate. Proceedings of the Royal Society of London. Series B 272, 887-895.

Jones, C.D., Kock, K.-H. and Balguerias, E. (2000) Changes in biomass of eight species of finfish around the South Orkney Islands (Subarea 48.2) from three bottom trawl surveys. CCAMLR Science 7, 53-74.

Jonker, F.C. and Bester, M.N. (1998) Seasonal movements and foraging areas of adult southern female elephant seals, Mirounga leonina, from Marion Island. Antarctic Science 10, 21-30.

Klages, N.T.W., Gales, R.P. and Pemberton, D. (1989) Dietary segregation of macaroni and rockhopper penguins at Heard Island. Australian Wildlife Research 16, 599-604.

Knecht, G.B. (2006) Hooked: Pirates, Poaching and the Perfect Fish. Holtzbrink Publishers, New York, 278 pp.

Kock, K.-H. (1992) Antarctic Fish and Fisheries. Cambridge University Press, Cambridge and New York, 359 pp.

Kock, K.-H. (1994) Fishing and conservation in southern waters. Polar Record 30, 3-22.

Kock, K.-H. (1998) Changes in the fish biomass around Elephant Island (Subarea 48.1) from 1976 to 1996. CCAMLR Science 5, 165-189.

Kock, K.-H. (2007) Antarctic Marine Living Resources exploitation and its management in the Southern Ocean. Antarctic Science 19, 231-238.

Kock, K.-H. and Jones, C.D. (2005) Fish Stocks in the southern Scotia Arc region - a review and prospectus 
for future research. Reviews in Fisheries Science 13, 75 108.

Kock, K.-H., Pshenichnov, L., Jones, C.D., Shust, K., Skora, K.E. and Frolkina, Z.A. (2004) Joinville-D’Urville Islands (Subarea 48.1) - a former fishing ground for the spiny icefish (Chaenodraco wilsoni), at the tip of the Antarctic Peninsula - revisited. CCAMLR Science 11, $1-20$.

Laevastu, T. (1993) Marine Climate, Weather and Fisheries. John Wiley and Sons, New York, 204 pp.

Laws, R.M. (1960) The southern elephant seal (Mirounga leonina) at South Georgia. Norwegian Hvalfangst Tidal, 10, 466-476, and 11, 520-542.

Laws, R.M. (1977a) Seals and whales of the Southern Ocean. Philosophical Transactions of the Royal Society of London. Series B 279, 81-96.

Laws, R.M. (1977b) The significance of vertebrates in the Antarctic marine ecosystem. In: Adaptations within Antarctic Ecosystem (ed. G.A. Llano). Gulf Publishing Company, Houston, pp. 411-438.

Laws, R.M. (1994) History and present status of southern elephant seal populations. In: Elephant Seals: Population Ecology, Behaviour and Physiology (eds B.J. LeBoeuf and R.M. Laws). University of California Press, Berkeley, pp. 49-65.

Lea, M.-A., Guinet, C., Cherel, Y., Duhamel, G., Dubroca, L., Pruvost, P. and Hindell, M. (2006) Impacts of climatic anomalies on provisioning strategies of a Southern Ocean predator. Marine Ecology Progress Series 310, 77-94.

Lefebvre, W., Goosse, H., Timmermann, R. and Fichefet, T. (2004) Influence of the Southern Annular Mode on the sea ice-ocean system. Journal of Geophysical Research 109, C09005, doi: 10.1029/2004JC002403.

Lenarz, W.H. (1980) Shortbelly rockfish, Sebastes jordani: a large unfished resource in waters off California. Marine Fisheries Review 42, 34-40.

Lescroël, A. and Bost, C.-A. (2006) Recent decrease in gentoo penguin populations at Iles Kerguelen. Antarctic Science 18, 171-174.

Lescroël, A., Ridoux, V. and Bost, C.-A. (2004) Spatial and temporal variation in the diet of the gentoo penguin (Pygoscelis papua) at Kerguelen Islands. Polar Biology 27, 206-216.

Longhurst, A. and Pauly, D. (1987) The Ecology of Tropical Oceans. Academic Press, San Diego, 407 pp.

Lynam, C., Gibbons, M., Axelsen, B., Sparks, C., Coetzee, J., Heywood, B. and Brierley, A. (2006) Jellyfish overtake fish in a heavily fished ecosystem. Current Biology 16, R492-R493.

Mantua, N.J. and Hare, S.R. (2002) The Pacific Decadal Oscillation. Progress in Oceanography 58, 35-44.

Matthews, L.H. (1978) Penguins, Whalers, and Sealers: a Voyage of Discovery. Universe Books, New York, 165 pp. McCafferty, D.J., Boyd, I.L., Walker, T.R. and Taylor, R.I. (1998) Foraging responses of Antarctic fur seals to changes in the marine environment. Marine Ecology Progress Series 166, 285-299.

McConnell, B.J., Chambers, C. and Fedak, M.A. (1992) Foraging ecology of southern elephant seals in relation to the bathymetry and productivity of the Southern Ocean. Antarctic Science 4, 393-398.

McConnell, B.J., Fedak, M.A., Burton, H.R., Engelhard, G.H. and Reijnders, P.J.H. (2002) Movements and foraging areas of naive, recently weaned elephant seals pups. Journal of Animal Ecology 71, 65-78.

McGowan, J.A., Cayan, D.R. and Dorman, L.M. (1998) Climate-ocean variability and ecosystem response in the Northeast Pacific. Science 281, 210-217.

McMahon, C.R., Burton, H.R. and Bester, M.N. (2003) A demographic comparison of two southern elephant seal populations. Journal of Animal Ecology 72, 61-74.

McMahon, C.R., Hindell, M.A., Burton, H.R. and Bester, M.N. (2005a) Comparison of southern elephant seal populations, and observations of a population on a demographic knife-edge. Marine Ecology Progress Series 288, 273-283.

McMahon, C.R., Bester, M.N., Burton, H.R., Hindell, M.A. and Bradshaw, C.J.A. (2005b) Population status, trends and a re-examination of the hypotheses explaining the recent declines of the southern elephant seal Mirounga leonina. Mammal Review 35, 82-100.

Mills, C.E. (2001) Jellyfish blooms: are populations increasing globally in response to changing ocean conditions? Hydrobiologia 451, 55-68.

Morato, T., Watson, R., Pitcher, T.J. and Pauly, D. (2006) Fishing down the deep. Fish and Fisheries $\mathbf{7}$. 24-34.

Murphy, R.C. (1981) The guano and the anchoveta fishery. In: Resource Management and Environmental Uncertainty: Lessons from Coastal Upwelling Fisheries (eds M.H. Glantz and J.D. Thompson). John Wiley \& Sons, New York, pp. 81-106.

Murphy, E.J., Watkins, J.L., Trathan, P.N. et al. (2007) Spatial and temporal operation of the Scotia Sea ecosystem: a review of large-scale links in a krill centred food web. Philosophical Transactions of the Royal Society of London. Series B 362, 113-148.

Myers, R.A. and Worm, B. (2003) Rapid worldwide depletion of predatory fish communities. Nature $\mathbf{4 2 3}$, 280-283.

Naveen, R., Forrest, S.C., Dagit, R.G., Blight, L.K., Trivelpiece, W.Z. and Trivelpiece, S.G. (2000) Censuses of penguin, blue-eyed shag, and southern giant petrel populations in the Antarctic Peninsula region, 19942000. Polar Record 36, 323-334.

Nicol, S. (2005) Krill, currents, and sea ice: Euphausia superba and its changing environment. BioScience $\mathbf{5 6}$ 11-120.

Nicol, S., Pauly, T., Bindoff, N.L. et al. (2000) Ocean circulation off east Antarctica affects ecosystem structure and sea-ice extent. Nature 406, 504-507. 
Nicol, S., Croxall, J., Trathan, P., Gale, N. and Murphy, E. (2007) Paradigm misplaced? Antarctic marine ecosystems are affected by climate change as well as biological processes and harvesting. Antarctic Science 19, 291295.

North, A.W., Croxall, J.P. and Doidge, D.W. (1983) Fish prey of Antarctic fur seal Arctocephalus gazella at South Georgia. British Antarctic Survey Bulletin 61, 27-37.

O'Brien, C.M., Fox, C.J., Planque, B. and Casey, J. (2000) Climate variability and North Sea cod. Nature 404, 142.

Oro, D. and Furness, R.W. (2002) Influences of food availability and predation on survival of kittiwakes. Ecology 83, 2516-2528.

Orsi, A.H., Whitworth, T. III and Nowlin, W.D. Jr (1995) On the meridional extent and fronts of the Antarctic Circumpolar Current. Deep-Sea Research I 42, 641-673.

Österblom, H., Casini, M., Olsson, O. and Bignert, A. (2006) Fish, seabirds and trophic cascades in the Baltic Sea. Marine Ecology Progress Series 323, 233-238.

Overholtz, W.J. and Link, J.S. (2007) Consumption impacts by marine mammals, fish, and seabirds on the Gulf of Maine-Georges Bank Atlantic herring (Clupea harengus) complex during the years 1977-2002. ICES Journal of Marine Science 64, 83-96.

Pakhomov, E.A. (1997) Feeding and exploitation of the food supply by demersal fishes in the Antarctic part of the Indian Ocean. Journal of Ichthyology 37, 360-380.

Pascal, M. (1985) Numerical changes in the population of elephant seals (Mirounga leonina) in the Kerguelen Archipelago during the past 30 years. In: Marine Mammals and Fisheries (eds J.R. Beddington, R.J.H. Beverton and D.M. Lavigne). Allen and Unwin, London, pp. 170-186.

Pauly, D. (1995) Anecdotes and the shifting baseline syndrome of fisheries. Trends in Ecology and Evolution 10, 430.

Pauly, D. and Maclean, J. (2003) In a Perfect Ocean: The State of Fisheries and Ecosystems in the North Atlantic Ocean. Island Press, Washington, DC, 175 pp.

Pauly, D. and Palomares, M.L. (2005) Fishing down marine food webs: it is far more pervasive than we thought. Bulletin of Marine Science 76, 197-211.

Pauly, D., Christiansen, V., Dalsgaard, J., Froeser, R. and Torres, F. Jr (1998) Fishing down marine food webs. Science 279, 860-863.

Pauly, D., Christensen, V., Guénette, S. et al. (2002) Toward sustainability in world fisheries. Nature $\mathbf{4 1 8}$, 689-695.

Pauly, D., Watson, R. and Alder, J. (2005) Global trends in world fisheries: impacts on marine ecosystems and food security. Philosophical Transactions of the Royal Society of London. Series B 360, 5-12.

Perry, A.L., Low, P.J., Ellis, J.R. and Reynolds, J.D. (2005) Climate change and distribution shifts in marine fishes. Science 308, 1912-1915.
Peterson, W.T. and Schwing, F.B. (2003) A new climate regime in northeast pacific ecosystems. Geophysical Research Letters 30, 1896.

Pistorius, P.A. and Bester, M.N. (2002) Juvenile survival and population regulation in southern elephant seals at Marion Island. African Zoology 37, 35-41.

Pistorius, P.A., Bester, M.N. and Kirkman, S.P. (1999a) Dynamic age distributions in a declining population of southern elephant seals. Antarctic Science 11, 445-450.

Pistorius, P.A., Bester, M.N. and Kirkman, S.P. (1999b) Survivorship of a declining population of southern elephant seals, Mirounga leonina, in relation to age, sex and cohort. Oecologia 121, 201-211.

Planque, B. and Taylor, A. (1998) Long-term changes in zooplankton and the climate of the North Atlantic. ICES Journal of Marine Science 55, 644-654.

Ralston, S. (2002) West coast groundfish harvest policy. North American Journal of Fisheries Management 22, 249250.

Reid, K. (1995) The diet of Antarctic fur seals Arctocephalus gazella (Peters 1875) during winter at South Georgia. Antarctic Science 7, 241-249.

Reid, K. and Croxall, J.P. (2001) Environmental response of upper trophic level predators reveals a system change in an Antarctic marine ecosystem. Proceedings of the Royal Society of London. Series B 268, 377-384.

Reid, K., Hill, S.L., Diniz, T.C.D. and Collin, M.A. (2005) Mackerel icefish Champsocephalus gunnari in the diet of upper trophic level predators at South Georgia: implications for fisheries management. Marine Ecology Progress Series 305, 153-161.

Reid, K., Davis, D. and Staniland, I.J. (2006) Spatial and temporal variation in the fish diet of Antarctic fur seals Arctocephalus gazella in the Atlantic Sector of the Southern Ocean. Canadian Journal of Zoology 84, 10251037.

Roche, C. and Guinet, C. (2007) Marine mammals and demersal longline fishery interactions in the Crozet and Kerguelen Exclusive Economic Zones: an assessment of depredation levels. CCAMLR Science 14, 67-82.

Scheffer, M., Carpenter, S. and De Young, B. (2005) Cascading effects of overfishing marine systems. Trends in Ecology and Evolution 20, 579-581.

Schrope, M. (2006) The real sea change. Nature 443 , 622-624.

Scientific Committee for Antarctic Research (SCAR) (2006) Proposal to de-list fur seals as specially protected species. Working Paper 39. Antarctic Treaty Consultative Meeting. Edinburgh, Scotland, 12-23 June 200613 pp. Siegel, V. (2005) Distribution and population dynamics of Euphausia superba: summary of recent findings. Polar Biology 29, 1-22.

Siniff, D.B., Garrott, J.R.A., Rotella, J.J., Fraser, W.R. and Ainley, D.G. (2008) Projecting the effects of environmental change on Antarctic seals. Antarctic Science 20, doi: $10.1017 /$ S0954102008001351. 
Slip, D.J. (1997) Foraging ecology of southern elephant seals from Heard Island. $\mathrm{PhD}$ thesis, University of Tasmania, Hobart, 168 pp.

Smetacek, V. and Nicol, S. (2005) Polar ocean ecosystems in a changing world. Nature 437, 362-368.

Stammerjohn, S.E., Martinson, D.G., Smith, R.C., Yuan, X. and Rind, D. (2008) Trends in Antarctic annual sea ice retreat and advance and their relation to ENSO and Southern Annular Mode variability. Journal of Geophysical Research 113, C03S90, doi: 10.1029/2007JC004269.

Thompson, P.M. and Ollason, J.C. (2001) Lagged effects of ocean climate change on fulmar population dynamics. Nature 413, 417-420.

Tovar, H., Guillen, V. and Nakama, M.E. (1987) Monthly population size of three guano bird species off Peru, 1953 to 1982. In: The Peruvian Anchoveta and Its Upwelling Ecosystem: Three Decades of Change (eds D. Pauly and I. Tsukayama). ICLARM Studies and Reviews 15, Instituto del Mar del Peru, Callao, pp. 208-218.

Trites, A.W.P., Livingston, M.C., Vasconcellos, S., Mackinson, A.M., Springer, A.M. and Pauly, D. (1999) Ecosystem change and the decline of marine mammals in the eastern Bering Sea: testing the ecosystem shift and commercial whaling hypothesis. In: Fisheries Centre Research Reports, Vol. 7. Fisheries Centre, University of British Columbia, Vancouver, 107 pp.

Tynan, C.T. (1998) Ecological importance of the southern boundary of the Antarctic Circumpolar Current. Nature 392, 708-710.

Van den Hoff, J., Burton, H.R., Hindell, M.A., Sumnet, M.D. and McMahon, C.R. (2002) Migrations and foraging of juvenile elephant seals from Macquarie Island within CCAMLR managed areas. Antarctic Science 14, 134-145.

Vandenbosch, R. (2000) Effects of ENSO and PDO events on seabird populations as revealed by Christmas bird count data. Waterbirds 23, 416-422.

Weimerskirch, H., Inchausti, P., Guinet, C. and Barbraud, C. (2003) Trends in bird and seal populations as indicators of a system shift in the Southern Ocean. Antarctic Science 15, 249-256.

Wilson, P.R., Ainley, D.G., Nur, N., Jacobs, S.S., Barton, K.J., Ballard, G. and Comiso, J.C. (2001) Adélie Penguin population change in the Pacific Sector of Antarctica: relation to sea-ice extent and the Antarctic Circumpolar Current. Marine Ecology Progress Series 213, 301-309.

Woehler, E.J. (2006) Status and conservation of the seabirds of Heard Island. In: Heard Island: Southern Ocean Sentinel (eds K. Green and E. Woehler). Surrey Beatty and Sons Pty. Ltd, Chipping Norton, pp. 128-165.

Woehler, E.J., Cooper, J., Croxall, J.P. et al. (2001) A Statistical Assessment of the Status and Trends of Antarctic and Subantarctic Seabirds. Scientific Committee on Antarctic Research, Cambridge, 45 pp.

Worm, B., Barbier, E.B., Beaumont, N. et al. (2006) Impacts of biodiversity loss on ocean ecosystem services. Science 314, 787-790.
Worm, B., Barbier, E.B., Beaumont, N. et al. (2007) Response to comments on "Impacts of biodiversity loss on ocean ecosystem services". Science 316, 1285-1286.

Xian, W., Kang, B. and Liu, R. (2005) Jellyfish blooms in the Yangtze estuary. Science 307, 41.

\section{Appendix 1}

References cited in Table 2 for their summary of diet, but not cited in the text of the document for other points made therein.

(23) Adams, N.J. and Klages, N.T. (1998) Temporal variation in the diet of gentoo penguin Pygoscelis papua at sub-Antarctic Marion Island. Colonial Waterbirds 12, 3038.

(21) Adams, N.J. and Wilson, M.-P. (1987) Foraging parameters of gentoo penguins Pygoscelis papua at Marion Island. Polar Biology 7, 51-56.

(6) Barrera-Oro, E. and Casaux, R. (1996) Fish as diet of the blue-eyed shag Phalacrocorax atriceps bransfieldensis at Half-Moon Island, South Shetland Islands. Cybium 20, $37-45$.

(42) Bonner, W.N. (1968) The fur seal of South Georgia. British Antarctic Survey, Scientific Report 56, $88 \mathrm{pp}$.

(47) Brown, D.J., Boyd, I.L., Cripps, G.C. and Butler, P.J. (1999) Fatty acid signature analysis from the milk of Antarctic fur seals and Southern elephant seals from South Georgia: implications for diet determination. Marine Ecology Progress Series 187, 251-263.

(18) Brown, C.R. and Klages, N.T. (1987) Seasonal and annual variation in diets of macaroni (Eudyptes chrysolophus) and southern rockhopper (Eudyptes crestatus) penguins at sub-Antarctic Marion Island. Journal of Zoology, London 212, 7-28.

(12) Casaux, R. (2003) On the accuracy of the pellet analysis method to estimate the food intake in the Antarctic shag, Phalacrocorax bransfieldensis. Folia Zoologica 52, 67-76.

(5) Casaux, R., Baroni, A. and Barrera-Oro, E. (2002) Fish in the diet of the Antarctic shag Phalacrocorax bransfieldensis breeding at four colonies in the Danco Coast, Antarctic Peninsula. Antarctic Science 14, 32-36.

(14) Casaux, R. and Barrera-Oro, E. (1993) The diet of the blue-eyed shag, Phalacrocorax atriceps bransfieldensis at the West Antarctic Peninsula. Antarctic Science 5, 335338.

(10) Casaux, R. and Barrera-Oro, E. (1998) Monitoring changes in coastal fish populations by the analysis of pellets of the Antarctic shag Phalacrocorax bransfieldensis: a new proposed standard method. CCAMLR Document WG-EMM-98/11, Hobart. 11 pp.

(39) Casaux, R., Bellizia, L. and Baroni, A. (2004) The diet of the Antarctic fur seal Arctocephalus gazella at Harmony Point, South Shetland Islands: evidence of 
opportunistic foraging on penguins? Polar Biology 27, 5965.

(4) Casaux, R., Coria, N. and Barrera-Oro, E. (1997b) Fish in the diet of the Antarctic shag Phalacrocorax bransfieldensis at Laurie Island, South Orkney Islands. Polar Biology 18, 219-222.

(7) Casaux, R., Favero, M., Coria, N. and Silva, P. (1997a) Diet of the imperial cormorant Phalacrocorax atriceps: comparison of pellets and stomach contents. Marine Ornithology 25, 1-4.

(11) Casaux, R., Favero, M., Silva, P. and Baroni, A. (2001) Sex differences in diving depths and diet of Antarctic shags at the South Shetland Islands. Journal of Field Ornithology 72, 22-29.

(14) Casaux, R. and Ramón, A. (2002) The diet of the South Georgia shag Phalacrocorax georgianus at the South Orkney Islands along five consecutive years. Polar Biology 25, 557-561.

(36) Casaux, R., Baroni, A. and Ramón, A. (2003a) The diet of the Antarctic fur seal Arctocephalus gazella at the Danco Coast, Antarctic Peninsula. Polar Biology 26, 49-54.

(41) Casaux, R., Baroni, A., Arrighetti, F., Ramón, A.and Carlini, A. (2003b) Geographical variation in the diet of the Antarctic fur seal Arctocephalus gazella. Polar Biology 26, 753-758.

(38) Casaux R, Baroni, A. and Carlini, A. (1998a) The diet of the Antarctic fur seal Arctocephalus gazella at Harmony Point, Nelson Island, South Shetland Islands. Polar Biology 20, 424-428.

(50) Cherel, Y., Guinet, C. and Tremblay, Y. (1997) Fish prey of Antarctic fur seals Arctocephalus gazella at Ile de Croy, Kerguelen. Polar Biology 17, 87-90.

(8) Coria, N., Casaux, R., Favero, M. and Silva, P. (1995) Analysis of the stomach content of the blue-eyed shag Phalacrocorax atriceps bransfieldensis at Nelson Island, South Shetland Islands. Polar Biology 15, 349-352.

(25) Coria N, Libertelli, M., Casaux, R. and Darrieu, C. (2000) Inter-annual variation in the autumn diet of the gentoo penguin at Laurie Island, Antarctica. Waterbirds 23, 511-517.

(52) Crawford, R.J.M., Cooper, J. and Dyer, B.M. (2003b) Population of the macaroni penguin Eudyptes chrysolophus at Marion Island 1994/95-2002/03, with information on breeding and diet. African Journal of Marine Science 25, 475-486.

(28) Croxall, J.P., Davis, R.W. and O'Connell, M.J. (1988b) Diving patterns in relation to diet of Gentoo and Macaroni penguins at South Georgia. Condor 90, 157167.

(16) Croxall, J.P., McCann, T.S., Prince, P.A. and Rothery, P. (1988a) Reproductive performance of seabirds and seals at South Georgia and Signy Island, South Orkney Islands, 1976-1978: implications for Southern Ocean monitoring studies. In: Antarctic Ocean and Resources Variability (ed. D. Sahrhage). Springer-Verlag, Berlin, pp. 261-285.
(19) Croxall, J.P and Prince, P.A. (1980) The food of gentoo penguins Pygoscelis pариа and macaroni penguins Eudyptes chrysolophus at South Georgia. Ibis 122, 245253.

(37) Daneri, G.A. (1996) Fish diet of the Antarctic fur seal, Arctocephalus gazella, in summer, at Stranger Point, King George Island, South Shetland Islands. Polar Biology 16, 353-355.

(46) Daneri, G.A. and Carlini, A.R. (2002) Fish prey of the southern elephant seals, Mirounga leonina, at King George Island. Polar Biology 25, 739-743.

(35) Daneri, G.A. and Coria, N.R. (1993) Fish prey of Antarctic fur seals, Arctocephalus gazella, during the summer-autumn period at Laurie Island, South Orkney Islands. Polar Biology 13, 287-89.

(3) Espitalier-Noel, H., Adams, N.J. and Klages, N.T. (1988) Diet of the imperial cormorant Phalacrocorax atriceps at Subantarctic Marion Island. Ети 88, 43-46.

(9) Favero, M., Casaux, R., Silva, P., Barrera-Oro, E. and Coria, N. (1998) The diet of the Antarctic shag during summer at Nelson Island, Antarctica. Condor 100, 112118.

(43) Green, K. and Burton, H.R. (1993) Comparison of the stomach contents of the southern elephant seal, Mirounga leonina, at Macquarie and Heard Islands. Marine Mammal Science 9, 10-22.

(30) Green, K., Burton, H. R. and Williams, R. (1989) The diet of Antarctic fur seals Arctocephalus gazella during the breeding season at Heard Island. Antarctic Science 1, $317-324$.

(22) Green, K., Slip, D.J. and Moore, G.J. (1998) The take of fish species by seabirds and marine mammals in the Australian Fisheries Zone around Heard Island: the potential for competition with a commercial fishery. Polar Biology 20, 273-280.

(15) Green, K. and Williams, R. (1997) Biology of the Heard Island shag Phalacrocorax nivalis. 3. Foraging, diet and diving behaviour. Ети 97, 76-83.

(31) Green K, Williams, R. and Burton, H.R. (1991) The diet of Antarctic fur seals during the late autumn and early winter around Heard Island. Antarctic Science 3, 359-361.

(32) Green K, Williams, R. and Burton, H.R. (1997) Foraging ecology of Antarctic fur seals (Arctocephalus gazella Peters) around Heard Island. In: Recent Marine Mammal Research in Australia and New Zealand (eds M.A. Hindell and C. Kemper). Surrey Beatty and Sons, Pty. Ltd., Sydney, pp. 105-113.

(1) Green, K., Williams, R., Woehler, E.J., Burton, H.R., Gales, N.J. and Jones, R.T. (1990) Diet of the Heard Island cormorant Phalacrocorax atriceps nivalis. Antarctic Science 2, 139-141.

(27) Karnovsky, N. (1997) The fish component of Pygoscelis penguin diet. MS Thesis, University of Montana, Bozeman. 88 pp.

(26) Kato, A., Williams, T. D., Barton, T. R. and Rodwell, S. (1991) Short-term variation in the winter diet 
of Gentoo Penguins Pygoscelis papua at South Georgia during July 1989. Marine Ornithology 19, 31-38.

(20) Klages, N.T.W., Gales, R.P. and Pemberton, D. (1989) Dietary segregation of macaroni and rockhopper penguins at Heard Island. Australian Wildlife Research 16, 599-604.

(51) Klages, N.T.W. and Bester, M.N. (1998) Fish prey of fur seals Arctocephalus spp. at subantarctic Marion Island. Marine Biology 131, 559-566.

(17) Klages, N.T.W., Pemberton, D. and Gales, R.P. (1990) The diet of king and gentoo penguins at Heard Island. Australian Wildlife Research 17, 53-60.

(45) Laws, R.M. (1960) The southern elephant seal (Mirounga leonina) at South Georgia. Norwegian Hvalfangst Tidal 10, 466-476, and 11, 520-542.

(33) Lea, M.-A., Guinet, C., Cherel, Y., Duhamel, G., Dubroca, L., Pruvost, P. and Hindell, M. (2006) Impacts of climatic anomalies on provisioning strategies of a Southern Ocean predator. Marine Ecology Progress Series 310. 77-94.

(24) Lescroël, A., Ridoux, V. and Bost, C.-A. (2004) Spatial and temporal variation in the diet of the gentoo penguin (Pygoscelis papua) at Kerguelen Islands. Polar Biology 27, 206-216.

(48) Murphy, R. C. (1914) Notes on the sea elephant, Mirounga leonina Linne. Bulletin of the American Museum of Natural History 33, 63-79.
(53) North, A.W., Croxall, J.P. and Doidge, D.W (1983) Fish prey of Antarctic fur seal Arctocephalus gazelle at South Georgia. British Antarctic Survey Bulletin 61, $27-37$.

(40) Osman, L.P., Hucke-Gaete, R., Moreno C.A. and Torres, D. (2004) Feeding ecology of Antarctic fur seals at Cape Shirreff, South Shetland Islands, Antarctica. Polar Biology 27, 92-98.

(34) Reid, K., Davis, D. and Staniland, I.J. (2006) Spatial and temporal variation in the fish diet of Antarctic fur seals Arctocephalus gazella in the Atlantic Sector of the Southern Ocean. Canadian Journal of Zoology 84, 1025 1037.

(2) Ridoux, V. (1994) The diets and dietary segregation of seabirds at the subantarctic Crozet Islands. Marine Ornithology 22, 1-192.

(13) Shaw, P. (1984) Factors affecting the breeding performance of the Antarctic blue-eyed Shag (Phalacrocorax atriceps bransfieldensis). Ph.D. thesis, University of Durham, UK. 88 pp.

(44) Slip, D.J. (1995) The diet of southern elephant seals (Mirounga leonina) at Heard Island. Canadian Journal of Zoology 73, 1519-1528.

(29) Williams, T.D. (1991) Foraging ecology and diet of Gentoo penguins Pygoscelis papua at South Georgia during winter and an assessment of their winter prey consumption. Ibis 133, 3-13. 